\title{
"Did you read about Berlin?" Terrorist attacks, online media reporting and support for refugees in Germany
}

\author{
Alexander W. Schmidt-Catran* and Christian S. Czymara** \\ Published in Soziale Welt (Volume 71, Issue 2-3, Pages 305-337), available at: \\ https://www.nomos-elibrary.de/10.5771/0038-6073-2020-1-2-201/did-you-read-about- \\ berlin-terrorist-attacks-online-media-reporting-and-support-for-refugees-in-germany- \\ volume-71-2020-issue-1-2
}

\begin{abstract}
We analyze whether the Islamist terror attack on the Christmas market in Berlin in 2016 had an impact on public opinion toward immigration in general and, since the attacker has entered Germany to apply for asylum, toward refugees in particular. An analysis of this natural experiment reveals a negative shift regarding the latter, while no differences are observed for the former. To shed more light on the driver of attitude change, we combine these findings with a quantitative content analysis of online media reporting about refugees before and after the attack. Mass media have long been considered to have an impact on exclusionary attitudes toward ethnic minorities. However, empirical evidence on this relationship remains largely anecdotal. We draw upon unsupervised machine learning to quantify the developments in reporting in three popular German online news websites. Results reveal that the attack had significant impact on media reporting on these websites. However, the strong focus on the attack was only short lived, quickly decreasing already in the second week after the attack. Linking media data to the public opinion data reveals no clear connection between reporting and attitudes. In contrast to theoretical expectations, descriptive evidence even shows that both follow almost opposite trends, since people changed their attitudes only weeks after the attack. We discuss potential explanations of these, at first sight, counterintuitive findings.
\end{abstract}

Keywords: Refugees; Terror Attack; Media; Natural Experiment; Migration

\footnotetext{
${ }^{*}$ Alexander W. Schmidt-Catran, Institute for Sociology, Goethe-University Frankfurt, Theodor-W-Adorno-Platz 6, 60323 Frankfurt am Main, E-Mail: alex@alexanderwschmidt.de

${ }^{* *}$ Christian S. Czymara, Institute for Sociology, Goethe-University Frankfurt, Theodor-W-Adorno-Platz 6, 60323 Frankfurt am Main, E-Mail: christian@czymara.com
} 


\section{„Hast du das über Berlin gelesen?“ \\ Terroristische Anschläge, Online-Berichterstattung und Einstellungen zu Flüchtlingen in Deutschland.}

Zusammenfassung: Wir untersuchen den Einfluss des islamistischen Terroranschlags auf den Berliner Weihnachtsmarkt in 2016 auf die öffentliche Meinung zu Migration im Allgemeinen und, da der Angreifer in Deutschland Asyl beantragt hatte, zu Flüchtlingen im Besonderen. Die Analyse dieses natürlichen Experiments zeigt, dass letztere negativer wurde, wohingegen allgemeine Einstellungen stabil geblieben sind. Um den Mechanismus hinter den Einstellungsänderungen näher zu beleuchten, kombinieren wir diese Ergebnisse mit einer quantitativen Inhaltsanalyse der medialen Berichterstattung über Flüchtlinge vor und nach dem Anschlag. Ein Einfluss medialer Berichterstattung auf negative Einstellungen gegenüber ethnischen Minderheiten wird häufig postuliert, bisher aber kaum empirisch getestet. Wir nutzen maschinelles Lernen, um die Berichterstattung in drei populären deutschen Onlinenachrichtenseiten über den Anschlag zu quantifizieren. Die Auswertung zeigt, dass der Anschlag einen signifikanten Effekt auf die Berichterstattung der drei Webseiten hatte, die mediale Aufmerksamkeit aber nur recht kurzlebig war und bereits in der zweiten Woche nach dem Anschlag deutlich abebbte. In den Daten zeigt sich daher kein direkter Zusammenhang zwischen medialer Berichterstattung und öffentlicher Meinung. Im Gegensatz zu den theoretischen Erwartungen suggerieren deskriptive Ergebnisse, dass die Entwicklung der öffentlichen Meinung sogar entgegengesetzt zur Berichterstattung zu laufen schien, da sich die Einstellungen erst Wochen nach dem eigentlichen Anschlag veränderten. Wir diskutieren mögliche Erklärungen dieser auf den ersten Blick kontraintuitiven Befunde.

Stichworte: Flüchtlinge; Terroranschlag; Medien; natürliches Experiment; Migration

\section{Introduction}

From 2015 to 2017, Europe has witnessed an unprecedented inflow of people applying for asylum. The number of asylum applications reached about 1.3 million, and thereby more than doubled compared to 2015 (Czymara 2020; Ziller/Heizmann 2020; Koos/Seibel 2019; Bansak/Hainmueller/Hangartner 2017). In total, Germany has by far been the most popular country of destination for refugees in Europe. More than a third of the refugees who entered EU territory applied for asylum in Germany (Connor 2016). These developments were met by dramatic events. For example, several acts of sexual harassment happened in Cologne and other German cities on New Year's Eve 2015/16 (Czymara/Schmidt-Catran 2017). Many public speakers and media reports directly connected these incidents to the fact that Germany received many refugees because the victims described the perpetrators primarily as men of "Arab or North African" appearance (Deutsche Welle 2018). On the other hand, Germany witnessed a massive rise in attacks against refugees and asylum shelters (Entorf/Lange 2019; Jäckle/König 2018). In this paper, we examine how the Islamist terror attacks in Berlin on 19 December 2016, which left 12 dead and 56 wounded, affected attitudes toward immigration in general and openness toward refugees specifically. To get behind the mechanism underlying (potential) changes in attitudes, we compare trends in public opinion to actual media reporting about refugees in popular German online media during this time. To this end, we draw upon latent Dirichlet allocation (Blei/Ng/Jordan 2003), an unsupervised machine learning approach to analyze large amounts of text, to extract the topics dominating media discourses in three major 
German news websites. We then descriptively compare the trends in media reporting before and after the Berlin attacks with attitudes using the German data from the European Social Survey.

\section{Terrorist attacks and public opinion}

It is an established finding in social science literature that threat perceptions are one of the core determinants of negative attitudes toward migrants and ethnic minorities (Hjerm 2007; Semyonov et al. 2004; Sides/Citrin 2007). This is based on the idea that migrants pose a threat to the majority group of a society (Blumer 1958). However, there is considerably less consensus on the question of what drives the perception of migrants as a threat. While some studies suggest that anti-immigrant attitudes correlate with a larger actual allochthonous population in a country (Meuleman/Davidov/Billiet 2009; Semyonov/Raijman/Gorodzeisky 2006; Quillian 1995; Blalock 1967), others argue that individual perceptions are largely disconnected from demographic reality (Herda 2010; Wong 2007; Hainmueller/Hopkins 2014).

In his classical paper, Blumer (1958) argues that ethnic prejudice is the result of the fear of losing privileges to ethnic minorities. "Big events" are particularly important for the emergence of a threatening image of minorities. In particular, he emphasizes the "... crucial role of the "big event" in developing a conception of the subordinate racial group. The happening that seems momentous, that touches deep sentiments, that seems to raise fundamental questions about relations, and that awakens strong feelings of identification with one's racial group is the kind of event that is central in the formation of the racial image" (Blumer 1958: 6, emphasizes added). Such events can lead to fears of losing what is considered as the traditional way of life or the national identity on the side of the ethnic majority members. Acts of terrorism are an extreme case of such an event. Due to their often fatal nature, terrorist attacks can not only be understood as a threat to values but also as a direct threat to individual or collective safety. It is hence somewhat surprising that many studies report a limited or even no impact of terrorist attacks on immigration related attitudes for many countries (for example, Brouard/Vasilopoulos/Foucault 2018; Finseraas/Jakobsson/Kotsadam 2011; Finseraas/Listhaug 2013; Silva 2018; Smiley/Emerson/Markussen 2017; Sniderman et al. 2019; but see, for example, Hopkins 2010; Legewie 2013).

Some of these studies draw upon secondary data of large survey programs where the fieldwork period coincided with a terror attack. Such attacks are assumed to be an external shock because they can hardly be predicted. That is, if the timing of interviews around an attack is random, those interviewed in the weeks before an event should not systematically differ from those interviewed after the event regarding relevant covariates. This corresponds to a natural experiment where the attack is the treatment, those interviewed after the attack are the treatment group and those interviewed before the attack are the control group. In this case, differences in attitudes between those interviewed before and after the attack can be causally attributed to the event because it is exogenous (Legewie 2013; Muñoz/Falcó-Gimeno/Hernández 2019). 
Legewie (2013) examines the European Social Survey (ESS) 2002 as well as the Eurobarometer 2004, which coincided with the Islamist terror attacks in Bali on 12 October 2002 and the Madrid train bombings in March 2004. Based on a regression discontinuity design that estimates the causal effect of the event, the Bali attack lead to significantly higher levels of anti-immigrant sentiment for two of nine countries in the ESS, where the fieldwork period coincided with the attack. The additional analysis of the Madrid bombing show that the effect is particularly strong for Spain itself, which suggests that domestic attacks are especially potent (but see, for example, Silva 2018). In a similar fashion, Finseraas et al. (2011) exploit the fact that the assassination of the Dutch film-maker Theo van Gogh by a radical Islamist in 2004 coincided with the fieldwork period of the second wave of the ESS to estimate a the causal treatment effect using a similar modeling strategy. This event indeed lead to immigration policy preferences that are more restrictive. In contrast to theoretical expectations, however, this effect seemed to be absent in the Netherlands. Similarly, Finseraas and Listhaug (2013) find no impact of the Islamist terror attacks in Mumbai 2008, which happened during the fourth wave of the ESS, on public opinion about immigration policies.

The first aim of this study is to test whether the Islamist attacks on a Christmas market in Berlin on 19 December 2016 led to lower levels of general acceptance of immigrants in Germany. This can be related to concerns about individual or collective safety as well as issues related to norms and values. It may be argued that a single attack does not threaten norms. However, one should keep in mind that this was not the first Islamist attack in Europe in recent years. This includes, amongst others, the Charlie Hebdo shooting and related attacks in Paris in January 2015 (Castanho Silva 2018), the attacks in Paris in November 2015 Paris attack with 130 fatalities (Jungkunz/Helbling/Schwemmer 2018) and the 2016 Nice truck attack (Brouard/Vasilopoulos/Foucault 2018) that killed 86 people, which was conducted very similarly to the Berlin attack on Christmas. Prior research indicates that effects of terror attacks on public opinion are rather short lived (Legewie 2013; Sniderman et al. 2019). However, we have argued elsewhere that "we assume that the effect of an event carries over and gets, at least partly, reactivated with each new event. This means that the effect of the most recent event of our analysis may cumulatively include parts of the events before" (Czymara/Schmidt-Catran 2017: 739). While we cannot test this assumption with the data at hand, we hypothesize a (latent) discontinuous threat that may even spill over to value related concerns about the national way of life. For these reasons, we have the following proposition:

Event-Proposition: The terror attacks in Berlin decreased support for immigration in Germany.

However, some scholars argue that an event should primarily affect attitudes toward the group that is connected to the event in public debates (Jungkunz/Helbling/Schwemmer 2018; de Rooij/Goodwin/Pickup 2015; Czymara/Schmidt-Catran 2017). Most discourses on ethnic minorities are particular and target specific (Meuleman et al. 2018), for example targeting Muslim immigration (Czymara 2019). There is no reason to assume that, for example, Islamist attacks affect attitudes toward the economic impact of immigration in general. Intermingling various dimensions of immigration attitudes by analyzing rather general survey items would, in this case, lead to a watering down of the actual effect on the attitude toward one particular group. 
There are studies that tackle this issue by having a more nuanced design, which allows differentiating attitudes toward different kinds of immigrants. And indeed, the results suggest that only attitudes toward those groups which are connected to a particular event do change (Czymara/Schmidt-Catran 2017; Jungkunz/Helbling/Schwemmer 2018). In the context of the present study, support for refugees might be especially affected by the Berlin attack because the attacker entered Germany to apply for asylum. The fact that the attacker entered Germany as a refugee was an important part in the debates after the attack. ${ }^{1}$ For example, on the day after the attack Spiegel Online released an article titled "Merkel: Act by a refugee would be particularly hard to bear." ${ }^{2}$ As we mentioned above, Germany by far took in most refugees in absolute numbers in Europe (Connor 2016). Hence, the Berlin attack and the larger context of the so-called "European Migrant Crisis" were intertwined. This leads to our second proposition:

Refugee-Proposition: The Berlin attack primarily decreased Germans' support for refugees, but did not alter attitudes toward immigrants in general.

\section{Mass media and attitudes toward ethnic minorities}

In a subsequent step, we aim to shed more light on the mechanism underlying the impact of the attack on individual attitudes. In particular, we incorporate an aspect that previous literature on terror effects vividly discussed but hardly tested empirically: mass media reporting. The recent intake of refugees was intensely discussed in the European media (Greussing/Boomgaarden 2017; Kluknavská/Bernhard/Boomgaarden 2019). The Berlin attack thus happened during a time when the refugee issue was generally very salient in public debates. We expect that the terrorist attack received much attention in the media due to its dramatic nature:

Media Salience-Proposition: The media strongly reacted to the Berlin attack.

However, whether and how this relates to trends in public opinion is an open question. After establishing whether the attack actually altered public opinion toward refugees in Germany, we examine the role of media reporting in this process. Mass media serve as the main source of information for most individuals because few experienced the event itself. Related uncertainty can result in a threatening and stereotypical depiction of ethnic minorities in the media (Esses/Medianu/Lawson 2013). Individuals may be directly and indirectly exposed to media information. Direct exposure implies the consumption of articles. However, people may also be indirectly exposed to such information, for example through interpersonal communication (Kalogeropoulos/Hopmann 2018) or social media (Bail et al. 2018; Flores 2017).

\footnotetext{
${ }^{1}$ Note that the attacker did not originate from the most popular sending countries of refugees (Syria, Iraq, Afghanistan), but from Tunisia. However, the relevant point for this paper is that he entered Germany as an asylum applicant.

${ }^{2}$ https://www.spiegel.de/politik/deutschland/angela-merkel-zu-berlin-tat-durch-fluechtling-waere-a-1126709.html. All translations by the authors.
} 
Several studies report an effect of media reporting on individual attitudes toward immigration and immigrants for Germany (Czymara/Dochow 2018; Boomgaarden/Vliegenthart 2009) and other European countries (Schemer 2012; Van Klingeren et al. 2015; Schlueter/Davidov 2013; Boomgaarden/Vliegenthart 2007). Moreover, Meeusen and Jacobs (2017) find that prejudice is especially strong for those ethnic groups that news media typically associate with problems, or crime related issues. Thus, the particular content of news seems to play an important role (McLaren/Boomgaarden/Vliegenthart 2018). In this reasoning, news reporting functions as a mediator between the event and the individual attitudes (Czymara 2018: $12 \mathrm{ff}$.). While we approach this question empirically in an explorative manner, it seems reasonable to expect that people's attitudes respond to developments in mass media reporting.

\section{Data and method3}

\subsection{Public opinion data}

To measure attitudes toward immigration in general and toward refugees in particular, we use the German data from the eighth wave of the European Social Survey (ESS8), edition ESS8e02. The fieldwork period of the ESS8 for Germany (23 August 2016 to 26 March 2017) coincides with the Berlin attack (19 December 2016), allowing us to analyze the consequences of the tragic event within the framework of a natural experiment.

To capture general attitudes toward immigration, one of our two dependent variables, we use three established items from the core module of the ESS: (1.) "Is Germany made a worse or a better place to live by people coming to live here from other countries?"; (2.) "Would you say that it is generally bad or good for Germany's economy that people come to live here from other countries?"; (3.) "Would you say that Germany's cultural life is generally undermined or enriched by people coming to live here from other countries?". Responses to these items are measured on 11-point scales ranging from negative [0] to positive [10] views on migration. We employed confirmatory factor analysis to identify the latent factor underlying these three items. Specifically, we estimated a multi-group model that tests for scalar measurement invariance between those interviewed before the event and those interviewed after the event. A one-factor model assuming scalar measurement invariance, i.e. comparability of the latent factor's levels, fitted the data very well $\left(\mathrm{Chi}^{2}=2.93(\mathrm{p}=0.71), \mathrm{RMSEA}=0.00\right)$ and we predicted the latent factor from this model (full model in Table A1 in the appendix).

To measure specific attitudes toward refugees, our second dependent variable, we use the following item: "Some people come to this country and apply for refugee status on the grounds that they fear persecution in their own country. Using this card, please say how much you agree or disagree that: 'the government should be generous in judging people's applications for refugee status'." The item uses a

\footnotetext{
${ }^{3} \mathrm{R}$ code and Stata do-files for replication are available at: https://dx.doi.org/10.17605/OSF.IO/Y5U84.
} 
five-point Likert-scale, ranging from "agree strongly" [1] to "disagree strongly" [5]. Thus, higher values mean a more critical attitude toward refugees.

The two dependent variables-general attitudes toward migration and specific attitudes toward refugees-are measured on different response scales. We therefore $z$-standardized both variables for the regression analysis, which allows a comparison of the effect sizes of the independent variables between the models. The factor score of general attitudes toward migration has also been reversed to align its direction with the item on refugees. Thus, for both dependent variables higher values indicate more critical attitudes toward migration respectively refugees.

To investigate the causal effect of the Berlin terror attack, we employ two different experimental designs. First, a standard experimental specification, in which we compare responses in their levels before and after the event. Second, a regression discontinuity alike design, which assumes that the trend in attitudes changed after the event. The former is implemented via a simple dummy variable, which is zero until (and including) the 19 December 2016 and one from the day after the attack. ${ }^{4}$ The latter is implemented via linear spline regressions, where the knot (i.e., the point at which the slopes are allowed to change) is the day after the attack. With this model, we want to test whether a change in attitudes happens gradually over time, as the media revealed the details of the attack. In contrast to a classical regression discontinuity design, our model assumes that there are no immediate effects of the attack; this is, there is no difference in levels right around the attack. ${ }^{5}$ Both designs were implemented with OLS regressions, which allowed us to also adjust for unbalanced covariates between the group of the treated and the non-treated. ${ }^{6}$

Covariates for the adjustment are sex (male=0, female=1), age and age squared (in years), education (ES-ISCED I [=reference], ES-ISCED II, ES-ISCED IIIa, ES-ISCED IIIb, ES-ISCED IV, ES-ISCED V1, ES-ISCED V2), employment status (employed [=reference], unemployed looking for a job, unemployed not looking for a job, permanently disabled, retired, housework, other), residence (Big city [=reference], suburbs, town or small city, country village, farm or countryside) and migration background (no=0, yes=1), which is defined as at least one parent being born outside Germany.

\footnotetext{
${ }^{4}$ Note that the attack took place in the evening of the 19 December, at about $8 \mathrm{pm}$. With one exception, all interviews conducted on that day were concluded before $8 \mathrm{pm}$. The last interview on the 19 December started at 8:24 pm and it is unlikely that the respondent has learned about the attack at that point in time. We therefore assume that the interviews conducted on the 19 December happened before the event.

${ }^{5}$ Such a model has also been tested and shows that there are indeed no level differences around the attack, once differences in the slopes of the trend variable are allowed. These results are available on request.

${ }^{6}$ We control for a variety of covariates to account for a potentially non-random distribution of interview dates. We used a logistic regression to test whether any of the mentioned covariates are related to the likelihood of being interviewed after the event. From 21 estimated coefficients, only two were statistically significant: Respondents living on farms or the countryside and retired people have a significantly lower probability to be interviewed after the event. Note that both of these variables do not correlate with the event dummy (compare Table A3 in the appendix). None of the other coefficients reaches common levels of significance. The full logit model can be found in the appendix (Table A2).
} 
The ESS8 includes in total $n=2,852$ observations from Germany. Following Legewie (2013), we excluded respondents who were not born in Germany or have no German citizenship ( $n=315)$; and we control for the migration background based on respondents' parents. In addition, respondents which had their interviews not within a day have also been excluded from the analysis $(n=162)$. For the regression analysis, we used listwise deletion on the observations $(n=39)$, leaving an analysis sample of $n=2,336$, of which 1,980 have been observed before the event and 356 afterwards. Table 1 shows descriptive statistics, Table A3 in the appendix presents correlations between all individual-level variables.

Table 1: Descriptive statistics

\begin{tabular}{|c|c|c|c|c|c|}
\hline Variable & $\mathrm{N}$ & Mean & Std. Dev. & Min & Max \\
\hline \multicolumn{6}{|l|}{ Individual-level survey data } \\
\hline \multicolumn{6}{|l|}{ Dependent variables: Attitudes toward } \\
\hline \multicolumn{6}{|l|}{$\ldots$} \\
\hline Immigration in general & 2336 & 0 & 1 & -2.194 & 2.621 \\
\hline Refugees & 2336 & 0 & 1 & -2.152 & 1.472 \\
\hline Event (dummy) & 2336 & 0.152 & 0.359 & 0 & 1 \\
\hline Linear spline before treatment (in days) & 2336 & 65.742 & 36.485 & 1 & 114 \\
\hline Linear spline after treatment (in days) & 2336 & 3.789 & 11.556 & 0 & 87 \\
\hline Age & 2336 & 49.202 & 18.591 & 15 & 94 \\
\hline $\mathrm{Age}^{2}$ & 2336 & 2766.336 & 1833.028 & 225 & 8836 \\
\hline \multicolumn{6}{|l|}{ Education (dummies) } \\
\hline ES-ISCED II & 2336 & 0.088 & 0.283 & 0 & 1 \\
\hline ES-ISCED IIIa & 2336 & 0.382 & 0.486 & 0 & 1 \\
\hline ES-ISCED IIIb & 2336 & 0.040 & 0.197 & 0 & 1 \\
\hline ES-ISCED IV & 2336 & 0.212 & 0.409 & 0 & 1 \\
\hline ES-ISCED V1 & 2336 & 0.104 & 0.305 & 0 & 1 \\
\hline ES-ISCED V2 & 2336 & 0.153 & 0.360 & 0 & 1 \\
\hline Female (dummy) & 2336 & 0.479 & 0.500 & 0 & 1 \\
\hline \multicolumn{6}{|l|}{ Residence (dummies) } \\
\hline Suburbs or outskirts of big city & 2336 & 0.143 & 0.351 & 0 & 1 \\
\hline Town or small city & 2336 & 0.379 & 0.485 & 0 & 1 \\
\hline
\end{tabular}




\begin{tabular}{|c|c|c|c|c|c|}
\hline Variable & $\mathrm{N}$ & Mean & Std. Dev. & Min & Max \\
\hline Country village & 2336 & 0.321 & 0.467 & 0 & 1 \\
\hline Farm or home in countryside & 2336 & 0.025 & 0.157 & 0 & 1 \\
\hline \multicolumn{6}{|l|}{ Employment status (dummies) } \\
\hline In education & 2336 & 0.093 & 0.290 & 0 & 1 \\
\hline Unemployed, looking for a job. & 2336 & 0.021 & 0.143 & 0 & 1 \\
\hline \multicolumn{6}{|l|}{ Unemployed, not looking for a } \\
\hline job & 2336 & 0.006 & 0.077 & 0 & 1 \\
\hline Permanently sick or disabled & 2336 & 0.017 & 0.130 & 0 & 1 \\
\hline Retired & 2336 & 0.246 & 0.431 & 0 & 1 \\
\hline Housework & 2336 & 0.060 & 0.238 & 0 & 1 \\
\hline Media data (article length in characters) & $\mathrm{N}$ (articles) & & & & \\
\hline Spiegel Online & 203 & 4921.355 & 3143.015 & 2001 & 31460 \\
\hline Welt Online & 851 & 5679.592 & 3522.788 & 2001 & 33027 \\
\hline Zeit Online & 162 & 8150.037 & 9007.851 & 2145 & 85971 \\
\hline
\end{tabular}

Source: ESS8e02, LexisNexis

\subsection{Media data}

We draw upon data from three of the largest online news websites in Germany, all with dozens of millions of visitors per month. ${ }^{7}$ These are Spiegel Online, Welt Online, and Zeit Online. Together these websites reach a very large audience and, in combination, are assumed to have a balanced ideological position. Hence, we use their output to proxy the media environment at large. Our goal is to capture pre- and post-attack media reporting about refugees. To this end, we used LexisNexis to download all articles about refugees that were published between 14 November 2016 and 23 January 2017; this is, from five weeks before the attack to five weeks afterwards. We define relevant articles as those including at least two terms related to refugees. ${ }^{8}$

\footnotetext{
${ }^{7}$ https://de.statista.com/statistik/daten/studie/547728/umfrage/anzahl-unique-visitors-von-nachrichten-websites-in-deutschland/.

${ }^{8}$ We used the following search string (! are wildcards): ATLEAST2(!flüchtling!). Results are similar when the string, in addition, includes "Geflüchteter" (synonym for refugee) or "Asylbewerber" (asylum applicant). We did not
} 
We used the R packages from Gruber (2019) and Benoit et al. (2018) for the data import and preprocessing. First, we deleted duplicates (defined as articles that are up to 97 percent similar), a common issue with LexisNexis data, as well as English articles, those with missing date, or those with less than 2,000 characters. This results in 1,216 unique articles on which our analyses are based. From these articles, we removed all punctuation, numbers, symbols, separators (such as white spaces), URLs, and stop words (commonly used words that do not have substantive meaning, such as articles ("der/die/das") or "in"). From this cleared data, we created a so-called document-term-matrix (DTM), where each row is a document (article), each column is a term (word) and each cell counts the occurrence of each term in each article. We remove all terms that occur in more than 50 percent or in less than one percent of articles because such terms do not differentiate well between topics. Hence, removing them enables better identification of meaningful structures in the text. This leaves us with 4,350 terms. Hence, our DTM has 1,216 rows (articles) and 4,350 columns (terms).

\subsection{Topic Modelling}

We employ Latent Dirichlet Allocation (LDA) on our DTM (Blei/Ng/Jordan 2003). LDA is a machine learning approach that identifies dominant clusters in the data without a priori restrictions and in an explorative manner. Topics, in this sense, are patterns of terms that cluster together. Put differently, some terms are more likely to be in one topic than in another. LDA relies on the bag-of-words assumption that each term in a text contributes to its meaning independent of its position therein (Boumans/Trilling 2016). It estimates models, which determine how a pre-defined number of topics are distributed across the collection of articles. For the present analysis, we chose ten topics. In an iterative process, LDA yields two posterior probability distributions: the distribution of terms within each topic and the distribution of topics within each article. In other words, there is one probability measure which indicates the likelihood for each term to be in a topic, theoretically ranging from zero (term certainly does not belong to the topic) to one (term certainly belongs to the topic). Similarly, the probabilities of the presence of each topic are calculated per article, also potentially ranging from zero (topic does not appear in the article at all) to one (article consists only of this topic). The probabilities of all terms to belong to a topic sum up to one and so do the probabilities of all topics to belong to an article. This means that if one topic has a higher value in a certain article, this article has to score lower on at least one other topic (Blei/Ng/Jordan 2003; Grimmer/Stewart 2013).

include search terms more broadly connected to immigration in order to minimize articles that are more broadly dealing with migration related issues but not refugees. 


\section{Results}

\subsection{Analysis of the impact of Berlin attack}

The upper panel of Figure 1 shows the development of attitudes toward refugee intake. The black vertical line marks the terror attack on 19 December 2016. This descriptive figure is relevant in several aspects. First, it is obvious that there is no strong and immediate effect of the terror attack. Second, the attitude seems to fluctuate quite a bit between the measurement points, which have been aggregated to weeks for this graphical presentation. ${ }^{9}$ This fluctuation makes it difficult to see whether there is any indication of an effect of the event. Nevertheless, the very strong fluctuations toward the end of the observation period is due to the ever-decreasing number of interviews per week, a figure presented in the histogram at the bottom of Figure 1. From the beginning of February until the end of March 2017, the average number of interviews was less than one interview per day. All data to the right side of the grey vertical line in Figure 1 are estimated from less than 30 observations in total. Consequently, the confidence intervals of these measures increase dramatically (and are, thus, not displayed) and we believe the pattern to the right side of the line should not be interpreted substantially.

The time trend between August and the end of January should be more reliable and may indicate an upward trend after the event. But again, the potential effect does neither appear to be immediate nor does it seem very strong. To test whether the data signal any significant effect of the terror attack, we present the regression analyses next.

Table 2 shows the results of two regression analyses. Models M1 to M4 test the effect of the event on the attitude toward refugees, while models M5 to M8 test for an effect on general attitudes toward immigration. The latter models do not show any significant effects of the event. Thus, we do not identify an effect of the terror attack on general attitudes toward immigration, leading us to refute our general Event-Proposition. In contrasts, there are some indications of an effect regarding the attitude toward refugees. Models 1 and 2 compare the level of this dependent variable between respondents interviewed before and after the attack. M1 does not adjust for unbalanced covariates and yields an effect of 0.142 ( $p=0.013$, two-sided test). Thus, people interviewed after the attack are significantly more critical of a liberal refugee policy. Model M2 includes controls to adjust for any non-random distribution of relevant covariates. The effect of the terror attack slightly decreases in model M2 to 0.117 but remains significant at the $5 \%$-level $(p=0.037$, two-sided test). Since the presented coefficients are semi-standardized, the adjusted effect of the attack (M2) is about 10 percent of a standard deviation.

\footnotetext{
${ }^{9}$ Weeks in all figures start on Tuesday because the attack happened on a Monday.
} 
Figure 1: Trend in attitude toward a liberal refugee policy in Germany

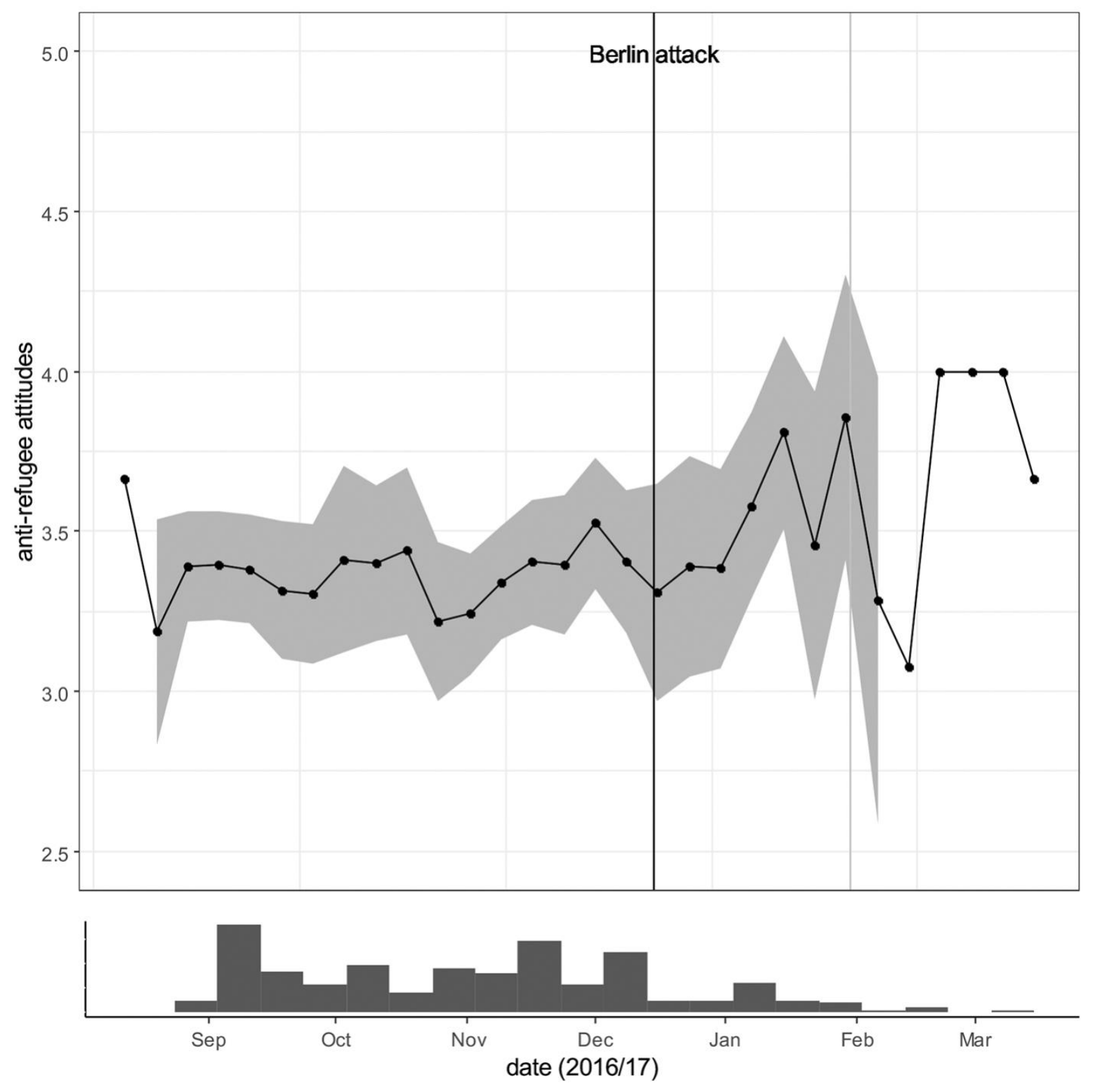

Note: The black line indicates weekly means of a negative attitude toward refugee intake, the grey area the $95 \%$ confidence intervals. The vertical black line is the attack and vertical grey line separates spares data. The histogram at the bottom presents the number of interviews.

Source: ESS8e02. 
Table 2: Regression of attitudes toward migration and refugees on treatment variables

\begin{tabular}{|c|c|c|c|c|c|c|c|c|}
\hline \multirow{3}{*}{$\begin{array}{l}\text { klein1 } \\
\text { Variable }\end{array}$} & \multicolumn{8}{|c|}{ Dependent variable } \\
\hline & \multicolumn{4}{|c|}{ Restrict asylum for refugees } & \multicolumn{4}{|c|}{$\begin{array}{l}\text { General attitudes towards migration } \\
\text { (factor) }\end{array}$} \\
\hline & M1 & M2 & M3 & M4 & M5 & M6 & M7 & M8 \\
\hline \multicolumn{9}{|l|}{$\begin{array}{l}\text { Treatment } \\
\text { variables }\end{array}$} \\
\hline \multicolumn{9}{|l|}{$\begin{array}{l}\text { Simple } \\
\text { experimental } \\
\text { design }\end{array}$} \\
\hline \multicolumn{9}{|l|}{$\begin{array}{l}\quad \text { Treatm } \\
\text { ent ( } 0 \\
\text { before } \\
\text { event, } 1 \\
\text { after } \\
\text { event) }\end{array}$} \\
\hline & $(0.058)$ & $(0.056)$ & & & $(0.058)$ & $(0.055)$ & & \\
\hline \multicolumn{9}{|l|}{$\begin{array}{l}\text { Regression } \\
\text { discontinuity } \\
\text { design }\end{array}$} \\
\hline \multirow[t]{2}{*}{$\begin{array}{l}\quad \text { Linear } \\
\text { spline } \\
\text { before } \\
\text { treatment } \\
\text { (days) }\end{array}$} & & & 0.000 & 0.000 & & & -0.001 & -0.001 \\
\hline & & & $(0.001)$ & $(0.001)$ & & & $(0.001)$ & $(0.001)$ \\
\hline \multirow[t]{2}{*}{$\begin{array}{l}\quad \text { Linear } \\
\text { spline } \\
\text { after } \\
\text { treatment } \\
\text { (days) }\end{array}$} & & & $0.005^{*}$ & $0.004 *$ & & & 0.003 & 0.003 \\
\hline & & & $(0.002)$ & $(0.002)$ & & & $(0.002)$ & $(0.002)$ \\
\hline \multicolumn{8}{|l|}{ Covariate } & \\
\hline Age & & $0.021 * *$ & & $0.022 * *$ & & 0.009 & & 0.010 \\
\hline $\mathrm{Age}^{2}$ & & $-0.000 * *$ & & $-0.000 * *$ & & -0.000 & & -0.000 \\
\hline $\begin{array}{l}\text { Education (ref.: } \\
\text { ES-ISCED I) }\end{array}$ & & & & & & & & \\
\hline
\end{tabular}




\begin{tabular}{|c|c|c|c|c|c|c|c|c|}
\hline \multirow{3}{*}{$\begin{array}{l}\text { klein1 } \\
\text { Variable }\end{array}$} & \multicolumn{8}{|c|}{ Dependent variable } \\
\hline & \multicolumn{4}{|c|}{ Restrict asylum for refugees } & \multicolumn{4}{|c|}{$\begin{array}{l}\text { General attitudes towards migration } \\
\text { (factor) }\end{array}$} \\
\hline & M1 & M2 & M3 & M4 & M5 & M6 & M7 & M8 \\
\hline \multicolumn{9}{|l|}{ ES- } \\
\hline ISCED II & & 0.151 & & 0.146 & & 0.261 & & 0.266 \\
\hline \multicolumn{9}{|l|}{ ES- } \\
\hline ISCED IIIa & & 0.241 & & 0.238 & & 0.257 & & 0.264 \\
\hline \multicolumn{9}{|l|}{ ES- } \\
\hline ISCED IIIb & & -0.194 & & -0.200 & & $-0.416 *$ & & $-0.411 *$ \\
\hline \multicolumn{9}{|l|}{ ES- } \\
\hline ISCED IV & & 0.171 & & 0.166 & & -0.057 & & -0.053 \\
\hline \multicolumn{9}{|l|}{ ES- } \\
\hline ISCED V1 & & 0.011 & & 0.006 & & -0.201 & & -0.196 \\
\hline \multicolumn{9}{|l|}{ ES- } \\
\hline ISCED V2 & & -0.183 & & -0.187 & & $-0.359 *$ & & $-0.354 *$ \\
\hline \multicolumn{9}{|l|}{ Gender (ref.: } \\
\hline \multicolumn{9}{|l|}{ Male) } \\
\hline Female & & 0.080 & & 0.080 & & 0.034 & & 0.034 \\
\hline \multicolumn{9}{|l|}{ Residence (ref.: } \\
\hline \multicolumn{9}{|l|}{ Big city) } \\
\hline Suburbs & & -0.016 & & -0.02 & & 0.132 & & 0.127 \\
\hline \multicolumn{9}{|l|}{ Town } \\
\hline $\begin{array}{l}\text { or small } \\
\text { city }\end{array}$ & & $0.223 * * *$ & & $\begin{array}{c}0.216 * * \\
*\end{array}$ & & $0.379 * * *$ & & $0.376 * * *$ \\
\hline \multicolumn{9}{|l|}{ Country } \\
\hline village & & $0.210 * *$ & & $0.208 * *$ & & $0.296 * * *$ & & $0.295^{* * *}$ \\
\hline $\begin{array}{l}\text { Farm or } \\
\text { countrysid } \\
\text { e }\end{array}$ & & 0.057 & & 0.055 & & 0.240 & & 0.242 \\
\hline $\begin{array}{l}\text { Main activity } \\
\text { (ref.: Employed) }\end{array}$ & & & & & & & & \\
\hline
\end{tabular}




\begin{tabular}{|c|c|c|c|c|c|c|c|c|}
\hline \multirow{3}{*}{$\begin{array}{l}\text { klein1 } \\
\text { Variable }\end{array}$} & \multicolumn{8}{|c|}{ Dependent variable } \\
\hline & \multicolumn{4}{|c|}{ Restrict asylum for refugees } & \multicolumn{4}{|c|}{$\begin{array}{l}\text { General attitudes towards migration } \\
\text { (factor) }\end{array}$} \\
\hline & M1 & $\mathrm{M} 2$ & M3 & M4 & M5 & M6 & M7 & M8 \\
\hline \multicolumn{9}{|l|}{ Educati } \\
\hline on & & $-0.206 *$ & & -0.198 & & $-0.203 *$ & & -0.194 \\
\hline $\begin{array}{l}\quad \text { Unempl } \\
\text { oyed, } \\
\text { looking for } \\
\text { job }\end{array}$ & & -0.059 & & -0.064 & & $0.543 * * *$ & & $0.541 * * *$ \\
\hline \multicolumn{8}{|l|}{ Unempl } & oyed, not \\
\hline \multicolumn{8}{|l|}{ job } & 0.216 \\
\hline \multicolumn{9}{|l|}{ Perman } \\
\hline $\begin{array}{l}\text { ently } \\
\text { disabled }\end{array}$ & & 0.061 & & 0.072 & & $0.351 *$ & & $0.355 *$ \\
\hline Retired & & 0.007 & & 0.010 & & 0.107 & & 0.109 \\
\hline \multicolumn{9}{|l|}{ Housew } \\
\hline ork & & -0.132 & & -0.128 & & -0.033 & & -0.028 \\
\hline Other & & -0.096 & & -0.09 & & -0.131 & & -0.124 \\
\hline $\begin{array}{l}\text { Migration } \\
\text { background } \\
\text { (ref.: no) }\end{array}$ & & -0.071 & & -0.070 & & $-0.166 * *$ & & $-0.165 * *$ \\
\hline Constant & -0.022 & $-0.643 * *$ & -0.039 & $-0.639 * *$ & 0.000 & $-0.457^{*}$ & 0.036 & -0.424 \\
\hline \multicolumn{9}{|l|}{ Statistics } \\
\hline AIC & $\begin{array}{c}6626.17 \\
0\end{array}$ & 6518.702 & 6625.632 & 6519.972 & 6632.280 & 6399.548 & 6631.689 & 6398.917 \\
\hline $\mathrm{BIC}$ & $\begin{array}{c}6637.68 \\
2\end{array}$ & 6651.095 & 6642.900 & 6658.121 & 6643.793 & 6531.941 & 6648.958 & 6537.065 \\
\hline $\mathrm{R}^{2}$ & 0.003 & 0.064 & 0.004 & 0.065 & 0.000 & 0.111 & 0.001 & 0.112 \\
\hline$N$ & 2336 & 2336 & 2336 & 2336 & 2336 & 2336 & 2336 & 2336 \\
\hline
\end{tabular}

Note: ${ }^{*} \mathrm{p}<0.05 ;{ }^{* *} \mathrm{p}<0.01 ;{ }^{* *} \mathrm{p}<0.001$ (two-sided tests). Standard errors of treatment variables in brackets. 
One explanation for the small effect size could be that the impact is not an immediate effect on the levels of the dependent variable but a change in the time trend, which is caused by the event and, as we argue here, build up by the media reports following in the aftermath of a terror attack. Therefore, models M3 and M4 use linear spline regressions to test whether the effect of the event is not on levels but on the time trend. Model M3 does indeed find that there is a significant upwards trend after the event (coefficient $=0.005, p=0.017$, two-sided test) but no trend before the attack (coefficient = 0.000). Model M4 adjusts the estimates for unbalanced covariates and yields the same conclusion. The effect of the event decreases slightly but remains significant at the $5 \%$-level (coefficient $=0.004, p=$ 0.043 , two-sided test). The measurement units of the linear splines are days, which means that the predicted increase in the dependent variable over a time period of, say, four weeks from the attack is about $0.112(0.004 * 7 * 4)$. Overall, we thus find supporting evidence for our Refugee-Proposition. However, the effect on specifically refugee-related attitudes appears to be limited in size.

We tested the significant treatment effects (Models M1 to M4) for their robustness with the help of placebo regressions. For these models, we used data from the previous, seventh, round of the ESS and treated December the $19^{\text {th }}$ of 2014 as a placebo (Muñoz et al. 2019: 13). None of the tested placebo treatments have a significant effect in these models, indicating that the effects found for the event of December $19^{\text {th }}$ in 2016 are indeed likely to be more than mere placebo effects (full results in Table A4 in the appendix). In the next section, we report the results of our media analysis and, subsequently, relate them to the development of the refugee attitude to check descriptively whether the upward trend in refugee-critical attitudes found in the public opinion data is associated with the media reporting about the attack.

\subsection{Descriptives of media data}

The output clearly structurally differs among the three news websites, as the last three rows in Table 1 show. Welt Online, which is usually considered the most conservative of the three outlets under investigation, published by far most articles about refugees. With 851 articles in total, it published more than four times as many as Spiegel Online $(n=203)$ and almost 6.5 times as many as Zeit Online $(n=162)$. However, articles published in Zeit Online are considerably longer compared to Spiegel Online and Welt Online. Quantitative differences in the output among the three outlets can also be observed in Figure 2, which shows the total number of articles published on each website over time (aggregated by week for the sake of clarity). Again, Welt Online clearly outperforms the other two in terms of quantity. Interestingly, even the trends seem to somewhat differ across the news websites. While Welt Online and Spiegel Online peak at the time of the attacks, which is indicated by the vertical line, this is not at all the case for Zeit Online. Moreover, attention in these news websites appears to be quite short lived, as the number of published articles about refugees clearly decreases in the week after the attack for all three websites. The fact that the coming weeks included Christmas and New Year's Eve is likely to have contributed to the lower level of news output during this time. This lends initial support to our Media Salience Expectation. However, a first peak two weeks before the Berlin attack is worth 
mentioning. We will return to this peak in the discussion of the topics. Before turning to the topics, we examine the content of the news articles.

Figure 2: Trends of online news reporting

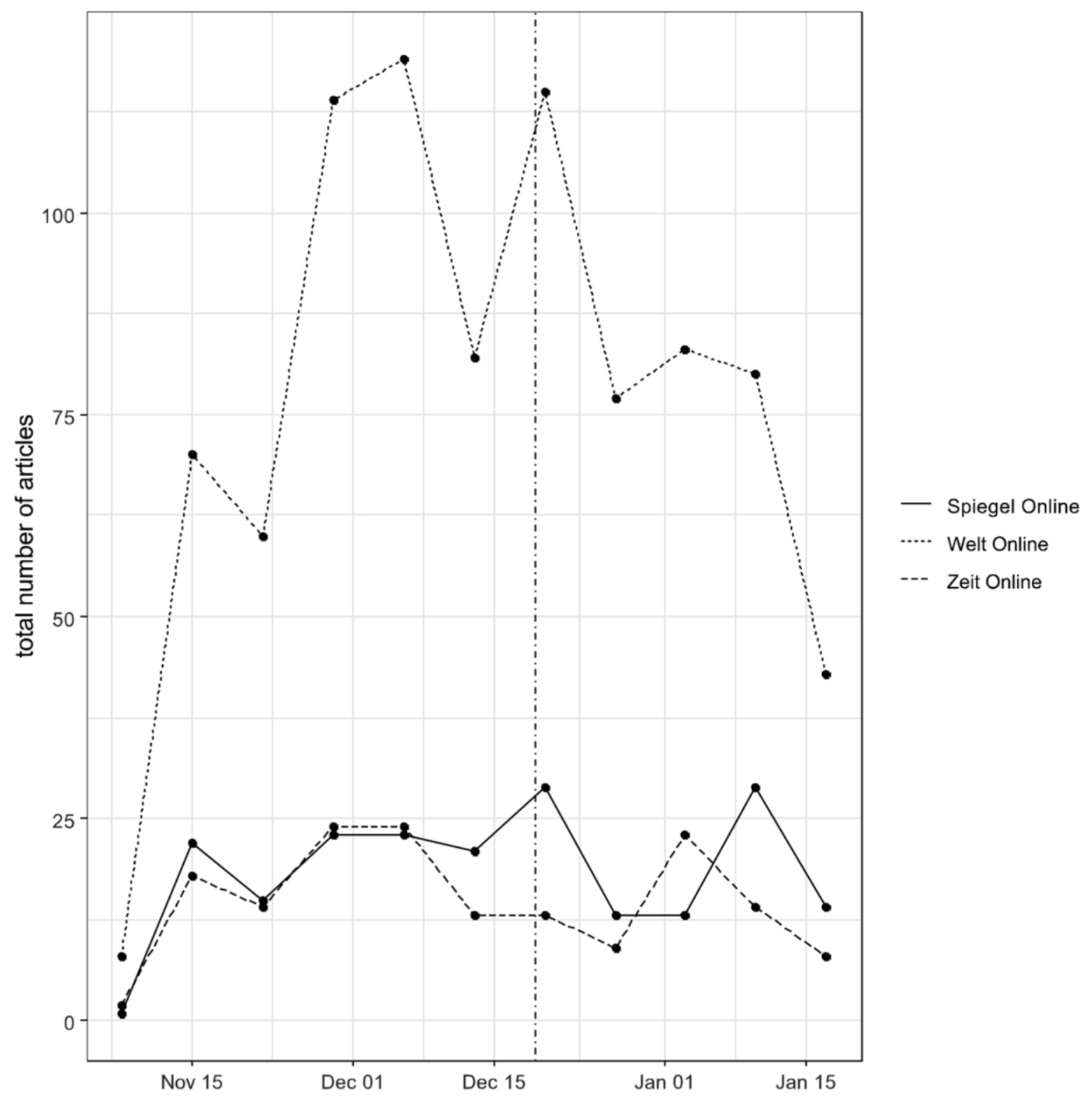

Source: LexisNexis.

Figure 3 shows the most frequent terms throughout the whole vocabulary in our corpus of online news articles. One can see that, generally speaking, politics seem to dominate the refugee issue, as the most frequent terms are Merkel (German chancellor), CDU (Merkel's party), Europa, EU (European Union) etc. However, the Berlin attack already shines through with terms like anschlag (attack) or amri (surname of the attacker). 
Figure 3: Most frequent terms in German online media reporting on refugees

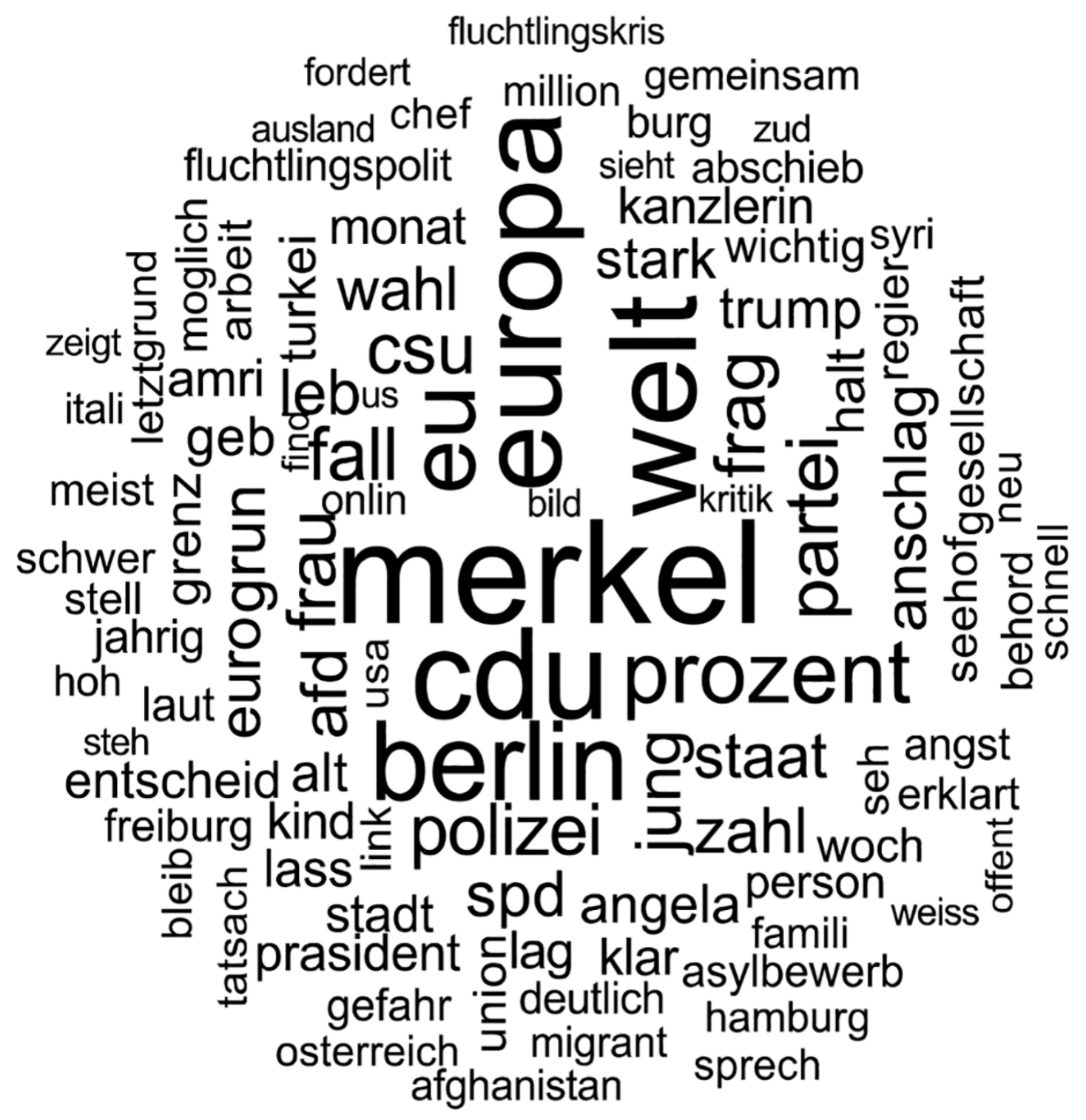

5.3 Topic definition and salience

The ten topics LDA yields are shown in Table A5 in the appendix, which includes the 20 (stemmed) terms with the highest probability to be in each topic. Our main interest is in topic 1 , which clearly and unambiguously captures the Berlin attacks. For example, the article where this topic is most prominent ${ }^{10}$ has the headline "Polish truck driver was shot dead"(Polnischer Beifahrer im

${ }^{10}$ Prominence here refers to the topic's posterior probability. We also refer to this probability as salience in this paper. 
Sattelschlepper wurde erschossen) and refers to the progression of the event. This article was published by Welt Online at 20 December and includes the attack topic with a probability of almost 80 percent. ${ }^{11}$ The top terms of the topic are berlin, anschlag (attack), amri (surname of the attacker), polizei (police), weihnachtsmarkt (Christmas market), and tunesi (referring to Tunisia, the attacker's country of origin). Most of these terms are directly connected to the attack itself. Moreover, while the origin (tunesi) and the Islamist motivation (islamist) was part of the narrative, it did not as prominently cover the fact that the attacker entered in Germany to apply for asylum since none of the top 20 terms in this topic relates to asylum or refugees.

Over the whole period of investigation, however, the Berlin attack is only the eighth prominent from the ten topics, with an average probability of nine percent. Since we are dealing with ten topics, one would expect a probability of ten percent if all topics would occur with the same frequency in the data. In total, topic nine, which deals with the German government and German politics in general, is most salient one, with a probability of about twelve percent. One reason for this finding is that the Berlin attack-topic is unlikely to be found and, by logic, not related to the attack of interest in the time before the event. Furthermore, the attention on the attack seems rather short-lived, which was already indicated by the fact that the total number of articles strongly decreased already in the week after the attack (see Figure 2).

Another outstanding topic is the second one, which captures the rape and murder of a female student in the German city of Freiburg, where the suspect was an Afghani asylum seeker. The capture and arrest of the suspect happened on December 3, 2016. This event explains the first peek in media reporting in the two weeks before the Berlin attacks in Figure 2. Across the whole collection, the Freiburg-topic is even a bit more prominent compared to the Berlin attack. It is, for example, the most dominant topic of 132 articles, ${ }^{12}$ whereas the Berlin attack is only the main topic of 100 articles.

Figure 4 shows that the topics follow plausible trends. The Berlin topic was negligible in the three news websites before the attack. ${ }^{13}$ In the week of the attack, however, the Berlin topic's salience rose from merely six percent to as much as 25 percent, which is by far the largest value across all topics and time points. While 25 percent might not seem very large, mind that it is the prominence of the topic in competition to all other topics combined during this time. Similar to the pattern of overall media reporting shown in Figure 2, we see that the relative media attention on the attack drops after the first week to values ranging between seven and eleven percent in all of the following weeks. Hence, the

11 The article is accessible here: https://www.welt.de/politik/deutschland/article160458218/Polnischer-Beifahrer-imSattelschlepper-wurde-erschossen.html.

12 The article most dominated by the Freiburg murder topic is titled "Murder of Maria L.; Suspects of age according to Greek authorities" (Mord an Maria L.; Tatverdächtiger soll laut griechischen Behörden volljährig sein) and published by Online (accessible at: https://www.welt.de/politik/deutschland/article160297275/Tatverdaechtiger-soll-laut-griechischen-Behoerden-volljaehrig-sein.html).

${ }^{13}$ Obviously, the media did not report on the attack itself in the period before it happened. The presence of the topic in the time prior to the attack just means that some terms that describe the attack topic also appear in articles before the attack (e.g.: Berlin, Police [polizei]). 
attack generated much attention when it happened, but the relative as well as the absolute attention quickly diminished, apparently. The other topics, in contrast, seem relatively stable over time. This further supports our Media Salience-Proposition.

Figure 4: Topic salience over time

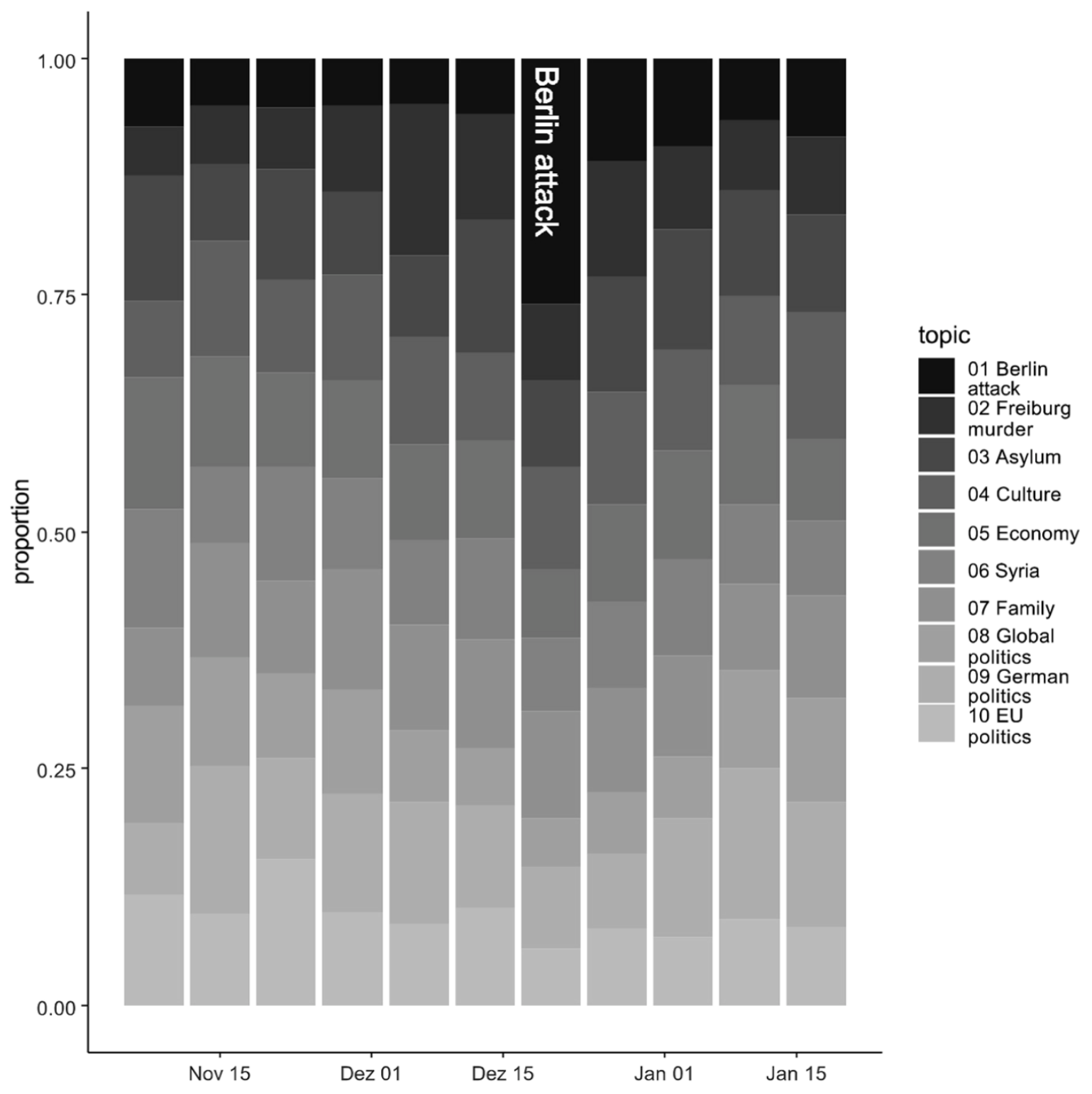

Source: LexisNexis. 
Figure 5: Covariation of media reporting on Berlin attack and attitude toward refugee intake

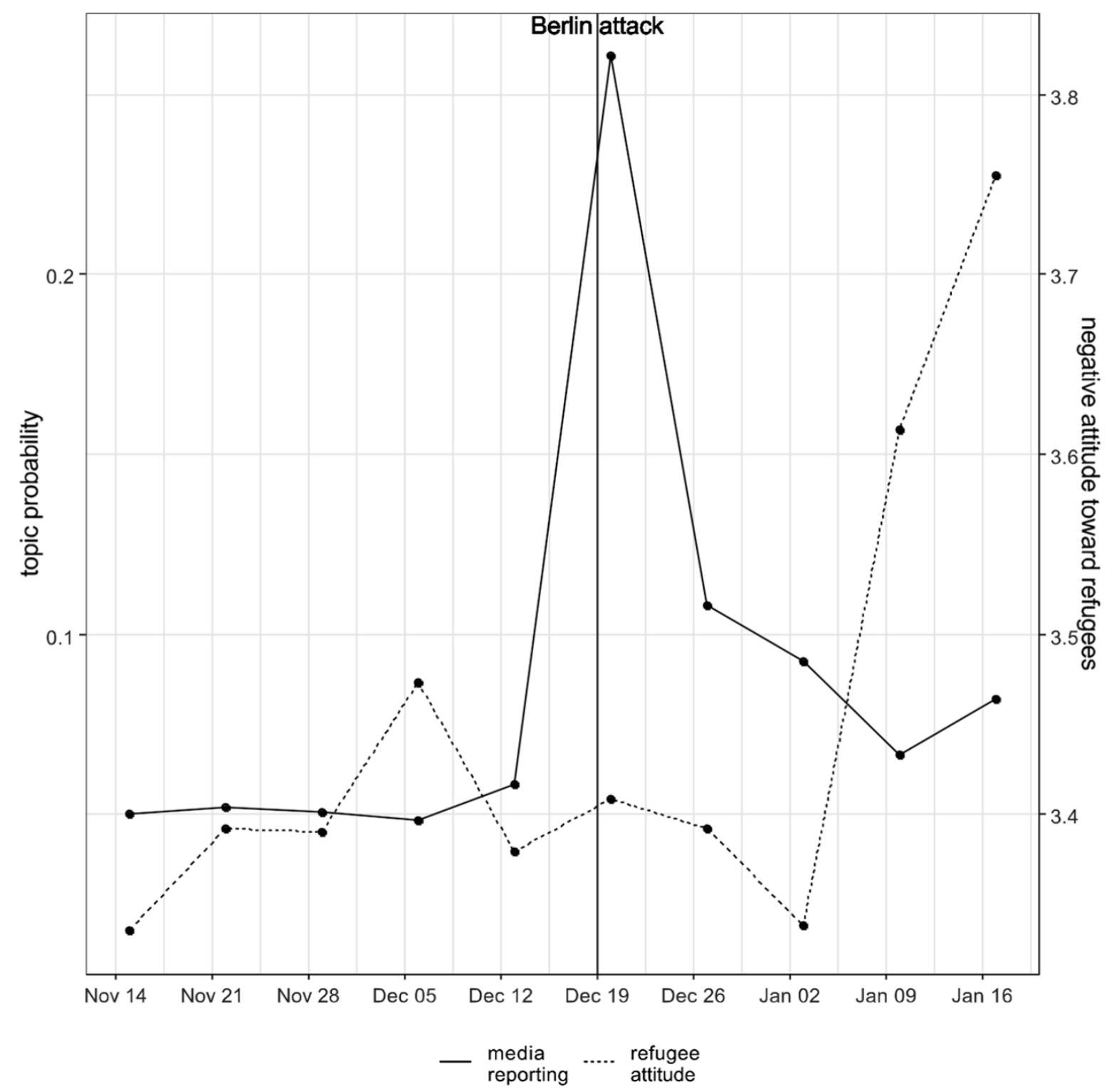

Source: ESS8e02, LexisNexis.

\subsection{Media reporting and attitudes}

In a final step, we want to compare online media reporting to the trends in German public opinion before and after the terror attack. Figure 5 shows the weekly trends in media reporting and a negative attitude toward refugees. Again, it is clearly visible how the event causes the media reporting on the topic, but also that the attention quickly fades. The public attitude, on the other hand, reacted significantly slower to the event. In fact, and contrary to theoretical expectations, respondents were relatively positive toward the intake of refugees in the week after the attack, which is when media reporting on refugees in the three online media outlets peaked. However, there is a steady tendency toward a more exclusionary attitude from the week after the attack on, with the most negative attitude 
five weeks after the event. Media reporting on the particular event is clearly already less salient during this time. Assuming that the three online outlets proxy the media environment at large, these descriptive results contradict the idea that mass media reporting directly triggers hostility toward refugees.

\section{Discussion}

Previous research demonstrates that mass media have considerable impact on people's attitudes toward immigration and immigrants (e.g.: Boomgaarden/Vliegenthart 2009; Czymara/Dochow 2018; Van Klingeren et al. 2015; Schlueter/Davidov 2013). Moreover, there is evidence that the way mass media report on ethnic minorities relates to their evaluation among the general public (Esses/Medianu/Lawson 2013; Meeusen/Jacobs 2017). This corresponds to recent developments in research on ethnic prejudice, which argues that attitudes have a specific component and that it is thus important to pay attention to the particular social context under investigation (Meuleman et al. 2018; Meeusen/Barlow/Sibley 2017). A society's immigration discourses relate more to certain immigrants than to others. This is why, for example, it is particularly hostility toward Muslim immigrants that is more widespread in countries where political elites are more exclusionary (Czymara 2019). Terrorist attacks can be considered as a strongly threatening event that boosts exclusionary attitudes (Finseraas/Jakobsson/Kotsadam 2011; Legewie 2013; Hopkins 2010), which should especially concern attitudes toward the ideological, ethnic or religious group of the attacker. In contrast, there is little reason to assume that such an event spills over on very general evaluations of immigration. In line with these theoretical considerations, we find that the attack on a Christmas market in Berlin did not alter Germans' overall view on immigration in general. We do find, however, that people's attitude toward the intake of refugees became less liberal over the weeks after the attack, which was conducted by a migrant who entered Germany to apply for asylum. Hence, it seems to be the case that mainly the attitude toward the group that is seemingly associated with the event are affected, refugees in our case. Put differently, the public seems to erroneously attribute the attack to the out-group at large. In different scenarios, this might refer more to other minorities. Hence, while the event in this particular context was connected to the intake of refugees, it is not per se associated with this group. However, the fact that refugee status, ethnicity, religious denomination and related aspects are often confounded in Europe complicates the isolation of the effect on one specific group only, especially with observational data. Experimental designs help in this respect (for example: Czymara/SchmidtCatran 2017). The use of rather general survey items may also explain why some studies on the impact of terror attacks do not find an effect on attitudes toward immigration in other European countries (Castanho Silva 2018; Smiley/Emerson/Markussen 2017; Finseraas/Listhaug 2013; Sniderman et al. 2019). However, it might also be that Germans reacted stronger to the attack because Germany was one of the key countries regarding the inflow of refugees in recent years (Czymara 2020; Connor 2016) and since the attack was, for Germany, the first of its kind with a larger number of fatalities.

Interestingly, attitudes became more negatively only weeks after the original attack. This may explain why Larsen, Cutts, and Goodwin (2019) do not report an effect of the Berlin attack on refugee attitudes 
using a design similar to ours. While they do not explicitly state their operationalization of "before" and "after" the attack, we assume that the "after" category was defined quite narrowly (similar to, for example, Legewie 2013). The definition of the "after" period is not trivial. On the one hand, a larger "after" period might make it harder to argue that the attack is the single cause of attitude change because more time implies more things happening in between receiving the treatment (the attack) and measurement of the outcome (the attitude). On the other hand, Muñoz, Falcc-Gimeno, and Hernnndez (2019) recently argued that examining shorter periods (a "narrower bandwidth") does not necessarily reduce bias of an estimated effect but will decrease statistical power due to the lower number of observations. Moreover, "the effects of certain types of events can take some time to unfold, and a narrow bandwidth might miss part of the effect or even lead to a false negative" (Muñoz et al. 2019: 11). Our analysis shows just that: It indeed seems to be the case that the change in attitudes was significantly lagged. This is in line with a quantitative content analysis of German Tweets after the Berlin attack, which reveals that xenophobia mainly rose at a later stage of the debates (FischerPreßler/Schwemmer/Fischbach 2019). Moreover, the analysis of Nägel and Lutter (2020) indicates that early attitude change is limited to certain segments of society, that is, to those with a right-wing political attitude.

Tracing the lagged effect in attitudes to actual reporting in three major German online news websites is, at least, not straightforward. Using machine-driven quantitative content analysis, we successfully identified the attack topic in the media reporting, which, perhaps unsurprisingly, peaked directly after the event. In the week after the attack, the topic made up 25 percent of the content of all news articles about refugees together. However, the data show that the focus on the attack seemed rather short lived. Already in the second week after the attack, the probability to observe the attack topic fell by fourteen percentage points. In contrast, the attitude toward refugee intake changed slowly over the course of several weeks. It might be that mass media primarily serve as a trigger that starts debates. Attitudes might, then, be more prone to subsequent discussions with peers in real life or over social media (Flores 2017). While such a mechanism is beyond the scope of the present study, it should be subject to future research.

There are other limitations of our study, which need to be addressed. If the time trend in the public's attitude toward refugee inflow were a result of the attack, one would expect the effect on a trend to reverse at some point or at least wear off (Sniderman et al. 2019). Unfortunately, this cannot be tested with the data at hand because the observation window (the ESS fieldwork) ended a few weeks after the attack. Another potentially disturbing factor is that the week directly after the attack included the Christmas holidays, followed by New Year's Eve, which might have influenced who participates in interviews. We tried to counter potential differences in treatment and control group by adjusting for several covariates, but one might argue that there are relevant unobserved characteristics. Furthermore, we assume our media data to capture the overall information environment as a contextual characteristic. While this approach has been used in previous research (Van Klingeren et al. 2015; Schlueter/Davidov 2013; Czymara/Dochow 2018), we cannot assure whether and to what degree individuals really are exposed to this information. It might be the case that our three news websites do not mirror the media that our analyzed respondents were really consuming or discussed 
with their peers. Since all three analyzed outlets can be considered classical or quality media, exposure to such outlets might also correlate with age, education, or ideological position. Unfortunately, items on the consumption of particular news outlets are hardly included in secondary survey data. Moreover, we cannot rule out the possibility that our news websites differ from the reporting of, for example, non-profit news websites or internet blogs. Nevertheless, we believe to contribute to the rising body of literature on terror effects as well as to studies linking public opinion to mass media.

\section{References}

Bail, Christopher A., Argyle, Lisa P., Brown, Taylor W., Bumpus, John P., Chen, Haohan, Hunzaker, M. B. Fallin, Lee, Jaemin, Mann, Marcus, Merhout, Friedolin \& Volfovsky, Alexander (2018): Exposure to Opposing Views on Social Media Can Increase Political Polarization. Proceedings of the National Academy of Sciences 115(37): 9216-21.

Bansak, Kirk, Hainmueller, Jens \& Hangartner, Dominik (2017): Europeans support a proportional allocation of asylum seekers. Nature Human Behaviour 1(7): 1-6.

Benoit, Kenneth, Watanabe, Kohei, Wang, Haiyan, Nulty, Paul, Obeng, Adam, Müller, Stefan \& Matsuo, Akitaka (2018): Quanteda: An R Package for the Quantitative Analysis of Textual Data. Journal of Open Source Software 3(30): 774.

Blalock, Hubert M. (1967): Toward a Theory of Minority-Group Relations. New York: John Wiley \& Sons In.

Blei, David M., Ng, Andrew Y. \& Michael I. Jordan (2003): Latent Dirichlet Allocation. Journal of Machine Learning Research 3: 993-1022.

Blumer, Herbert (1958): Race Prejudice as a Sense of Group Position. The Pacific Sociological Review 1(1): 3-7.

Boomgaarden, Hajo G. \& Vliegenthart, Rens (2007): Explaining the Rise of Anti-Immigrant Parties: The Role of News Media Content. Electoral Studies 26(2): 404-17.

Boomgaarden, Hajo G. \& Vliegenthart, Rens (2009): How News Content Influences Anti-Immigration Attitudes: Germany, 1993-2005. European Journal of Political Research 48(4): 516-42.

Boumans, Jelle W. \& Trilling, Damian (2016): Taking Stock of the Toolkit: An Overview of Relevant Automated Content Analysis Approaches and Techniques for Digital Journalism Scholars. Digital Journalism 4(1): 8-23. 
Brouard, Sylvain, Vasilopoulos, Pavlos \& Foucault, Martial (2018): How Terrorism Affects Political Attitudes: France in the Aftermath of the 2015-2016 Attacks. West European Politics 41(5): 1073-99.

Castanho Silva, Bruno. (2018): The (Non)Impact of the 2015 Paris Terrorist Attacks on Political Attitudes. Personality and Social Psychology Bulletin 44(6): 838-50.

Connor, Phillip (2016): Number of Refugees to Europe Surges to Record 1.3 Million in 2015, http://www.Pewglobal.Org/2016/08/02/Number-of-Refugees-to-Europe-Surges-to-Record-1-3Million-in-2015/, Accessed: 2019-02-12. Pew Research Center. 2016.

Czymara, Christian S. (2020): Attitudes toward refugees in contemporary Europe: A longitudinal perspective on cross-national differences. Social Forces, https://doi.org/10.1093/sf/soaa055.

Czymara, Christian S. (2019): Propagated Preferences? Political Elite Discourses and Europeans' Openness toward Muslim Immigrants. International Migration Review, https://doi.org/10.1177/0197918319890270.

Czymara, Christian S. (2018): Discursive Determinants of Attitudes towards Immigrants: Political Parties and Mass Media as Contextual Sources of Threat Perceptions. University of Cologne.

Czymara, Christian S. \& Dochow, Stephan (2018): Mass Media and Concerns about Immigration in Germany in the 21st Century: Individual-Level Evidence over 15 Years. European Sociological Review 34(4): 381-401.

Czymara, Christian S. \& Schmidt-Catran, Alexander W. (2017): Refugees Unwelcome? Changes in the Public Acceptance of Immigrants and Refugees in Germany in the Course of Europe's 'Immigration Crisis. European Sociological Review 33(6): 735-51.

Deutsche Welle (2018): Migration 'mother of All Political Problems,' Says German Interior Minister Horst Seehofer, https://www.Dw.Com/En/Migration-Mother-of-All-Political-Problems-Says-GermanInterior-Minister-Horst-Seehofer/a-45378092, Accessed: 2018-09-06. 2018.

Entorf, Horst \& Lange, Martin (2019): Refugees Welcome? Understanding the Regional Heterogeneity of Anti-Foreigner Hate Crimes in Germany. Mannheim.

Esses, Victoria M., Medianu, Stelian \& Lawson, Andrea S. (2013): Uncertainty, Threat, and the Role of the Media in Promoting the Dehumanization of Immigrants and Refugees. Journal of Social Issues 69(3): 518-36.

Finseraas, Henning, Jakobsson, Niklas \& Kotsadam, Andreas (2011): Did the Murder of Theo van Gogh Change Europeans' Immigration Policy Preferences? Kyklos 64(3): 396-409. 
Finseraas, Henning \& Listhaug, Ola (2013): It Can Happen Here: The Impact of the Mumbai Terror Attacks on Public Opinion in Western Europe. Public Choice 156(1-2): 213-28.

Fischer-Preßler, Diana, Schwemmer, Carsten \& Fischbach, Kai (2019): Collective Sense-Making in Times of Crisis: Connecting Terror Management Theory with Twitter User Reactions to the Berlin Terrorist Attack. Computers in Human Behavior 100: 138-51.

Flores, René D. (2017): Do Anti-Immigrant Laws Shape Public Sentiment? A Study of Arizona's SB 1070 Using Twitter Data. American Journal of Sociology 123(2): 333-84.

Greussing, Esther \& Boomgaarden, Hajo G. (2017): Shifting the Refugee Narrative? An Automated Frame Analysis of Europe's 2015 Refugee Crisis. Journal of Ethnic and Migration Studies.

Grimmer, Justin \& Stewart, Brandon M. (2013): Text as Data: The Promise and Pitfalls of Automatic Content Analysis Methods for Political Texts. Political Analysis 21(3): 267-97.

Gruber, Johannes (2019): LexisNexisTools. An R Package for Working with Newspaper Data from 'LexisNexis.'

Hainmueller, Jens \& Hopkins, Daniel J. (2014): Public Attitudes Toward Immigration. Annual Review of Political Science 17(1): 225-49.

Heizmann, Boris \& Ziller, Conrad (2020): Who is willing to share the burden? Attitudes towards the allocation of asylum seekers in comparative perspective. Social Forces 98(3): 1026-1051.

Herda, Daniel (2010): How Many Immigrants? Foreign-Born Population Innumeracy in Europe. Public Opinion Quarterly 74(4): 674-95.

Hjerm, Mikael (2007): Do Numbers Really Count? Group Threat Theory Revisited. Journal of Ethnic and Migration Studies 33(8): 1253-75.

Hopkins, Daniel J. (2010): Politicized Places: Explaining Where and When Immigrants Provoke Local Opposition. American Political Science Review 104(1): 40-60.

Jäckle, Sebastian \& König, Pascal D. (2018): Threatening Events and Anti-Refugee Violence: An Empirical Analysis in the Wake of the Refugee Crisis during the Years 2015 and 2016 in Germany. European Sociological Review: 1-16.

Jungkunz, Sebastian, Helbling, Marc \& Schwemmer, Carsten (2018): Xenophobia before and after the Paris 2015 Attacks: Evidence from a Natural Experiment. Ethnicities. 
Kalogeropoulos, Antonis \& Hopmann, David Nicolas (2018): Interpersonal Discussions and Immigration Attitudes. Communications 0(0).

Klingeren, Marijn Van, Boomgaarden, Hajo G., Vliegenthart, Rens \& De Vreese, Claes H. (2015): Real World Is Not Enough: The Media as an Additional Source of Negative Attitudes Toward Immigration, Comparing Denmark and the Netherlands. European Sociological Review 31(3): 268-283.

Kluknavská, Alena, Bernhard, Jana \& Boomgaarden, Hajo G (2019): Claiming the Crisis: Mediated Public Debates about the Refugee Crisis in Austria, the Czech Republic and Slovakia. Journal of Refugee Studies 0(0).

Koos, Sebastian \& Seibel, Verena (2019): Solidarity with refugees across Europe. A comparative analysis of public support for helping forced migrants. European Societies 21(5): 704-728.

Larsen, Erik Gahner, Cutts, David \& Goodwin, Matthew J. (2019): Do Terrorist Attacks Feed Populist Eurosceptics? Evidence from Two Comparative Quasi-Experiments. European Journal of Political Research: 1-24.

Legewie, Joscha (2013): Terrorist Events and Attitudes toward Immigrants: A Natural Experiment. American Journal of Sociology 118(5): 1199-1245.

McLaren, Lauren M., Boomgaarden, Hajo G. \& Vliegenthart, Rens (2018): News Coverage and Public Concern about Immigration in Britain. International Journal of Public Opinion Research 30(2): 173-93.

Meeusen, Cecil, Barlow, Fiona Kate \& Sibley, Chris G. (2017): Generalized and Specific Components of Prejudice: The Decomposition of Intergroup Context Effects. European Journal of Social Psychology 47(4): 443-56.

Meeusen, Cecil \& Jacobs, Laura (2017): Television News Content of Minority Groups as an Intergroup Context Indicator of Differences Between Target-Specific Prejudices. Mass Communication and Society 20(2): 213-40.

Meuleman, Bart, Abts, Koen, Slootmaeckers, Koen \& Meeusen, Cecil (2018): Differentiated Threat and the Genesis of Prejudice: Group-Specific Antecedents of Homonegativity, Islamophobia, AntiSemitism, and Anti-Immigrant Attitudes. Social Problems.

Meuleman, Bart, Davidov, Eldad \& Billiet, Jaak (2009): Changing Attitudes toward Immigration in Europe, 2002-2007: A Dynamic Group Conflict Theory Approach. Social Science Research 38(2): 35265. 
Muñoz, Jordi, Falcó-Gimeno, Albert \& Hernández, Enrique (2019): Unexpected Event During Surveys Design: Promise and Pitfalls. Political Analysis. https://doi.org/10.2139/ssrn.3159194.

Nägel, Christof \& Lutter, Mark (2020): The Christmas Market Attack in Berlin and Attitudes Toward Refugees : A Natural Experiment with Data from the European Social Survey. European Journal for Security Research.

Quillian, Lincoln (1995): Prejudice as a Response to Perceived Group Threat: Population Composition and Anti-Immigrant and Racial Prejudice in Europe. American Sociological Review 60(4): 586.

Rooij, Eline A. de, Goodwin, Matthew J. \& Pickup, Mark (2015): Threat, Prejudice and the Impact of the Riots in England. Social Science Research 51: 369-83.

Schemer, Christian (2012): The Influence of News Media on Stereotypic Attitudes Toward Immigrants in a Political Campaign. Journal of Communication 62(5): 739-57.

Schlueter, Elmar \& Davidov, Eldad (2013): Contextual Sources of Perceived Group Threat: Negative Immigration-Related News Reports, Immigrant Group Size and Their Interaction, Spain 1996-2007. European Sociological Review 29(2): 179-91.

Semyonov, Moshe, Raijman, Rebeca \& Gorodzeisky, Anastasia (2006): The Rise of Anti-Foreigner Sentiment in European Societies, 1988-2000. American Sociological Review 71(3): 1988-2000.

Semyonov, Moshe, Raijman, Rebeca, Yom Tov, Anat \& Schmidt, Peter (2004): Population Size, Perceived Threat, and Exclusion: A Multiple-Indicators Analysis of Attitudes toward Foreigners in Germany. Social Science Research 33(4): 681-701.

Sides, John \& Citrin, Jack (2007): European Opinion About Immigration: The Role of Identities, Interests and Information. British Journal of Political Science 37(3): 477-502.

Smiley, Kevin T., Emerson, Michael Oluf \& Werner Markussen, Julie (2017): Immigration Attitudes Before and After Tragedy in Copenhagen: The Importance of Political Affiliation and Safety Concerns. Sociological Forum 32(2): 321-38.

Sniderman, Paul M., Bang Petersen, Michael, Slothuus, Rune, Stubager, Rune \& Petrov, Philip (2019): Reactions to Terror Attacks: A Heuristic Model. Political Psychology 40(S1): 245-58.

Wong, Cara J. (2007): 'Little' and 'Big' Pictures in Our Heads. Race, Local Context, and Innumeracy About Racial Groups in the United States. Public Opinion Quarterly 71(3): 393-412. 


\section{Appendix}

Table A1: Multi-group confirmatory factor analysis testing for scalar measurement invariance

\begin{tabular}{|c|c|c|c|c|}
\hline & \multicolumn{2}{|c|}{ Before attack } & \multicolumn{2}{|c|}{ After attack } \\
\hline & Loading & Constant & Loading & Constant \\
\hline Country worse or better & 2.027 & -5.160 & 2.027 & -5.160 \\
\hline Bad or good for economy & 1.675 & -5.815 & 1.675 & -5.815 \\
\hline Culture undermined or enriched & 2.060 & -5.947 & 2.060 & -5.947 \\
\hline \multicolumn{5}{|l|}{ Error variances } \\
\hline Country worse or better & \multicolumn{2}{|c|}{0.988} & \multicolumn{2}{|c|}{0.753} \\
\hline Bad or good for economy & \multicolumn{2}{|c|}{2.510} & \multicolumn{2}{|c|}{2.645} \\
\hline Culture undermined or enriched & \multicolumn{2}{|c|}{1.932} & \multicolumn{2}{|c|}{1.961} \\
\hline
\end{tabular}

Note: Variance of latent factor is restricted to $1 . \mathrm{RMSEA}=0.00, \mathrm{Chi}^{2}=2.93(\mathrm{p}=0.71)$.

Source: ESS8e02.

Table A2: Logistic regression of treatment on covariates

\begin{tabular}{lc}
\hline Variable & Coefficient \\
\hline Age & 0.000 \\
Age $^{2}$ & 0.000 \\
Education (ref.: ES-ISCED I) & \\
$\quad$ ES-ISCED II & -0.272 \\
ES-ISCED IIla & -0.066 \\
ES-ISCED IIIb & -0.532 \\
ES-ISCED IV & -0.139 \\
ES-ISCED V1 & -0.249 \\
ES-ISCED V2 & -0.394 \\
Female (dummy) & 0.131 \\
Residence (ref.: Big city) \\
Suburbs or outskirts of big city
\end{tabular}


Town or small city

Country village

Farm or home in countryside

Employment status (ref.: Paid work)

In education

Unemployed, looking for a job.

Unemployed, not looking for a job

Permanently sick or disabled

Retired

Housework

Other

Migration background (dummy)

Constant $-1.005$

Notes: Logit coefficients; $* p<0.05,{ }^{* *} p<0.01,{ }^{* * *} p<0.001$ (two-sided tests).

Source: ESS8e02.

Table A3: Correlations of all individual-level variables

\begin{tabular}{|c|c|c|c|c|c|c|c|c|c|c|c|c|c|c|c|c|c|c|}
\hline Variable klein5 & 1 & 2 & 3 & 4 & 5 & 6 & 7 & 8 & 9 & 10 & 11 & 12 & 13 & 14 & 15 & 16 & 17 & 18 \\
\hline \multicolumn{19}{|l|}{$\begin{array}{l}\text { Dependent } \\
\text { variables: } \\
\text { Attitudes } \\
\text { toward ... }\end{array}$} \\
\hline \multicolumn{19}{|l|}{$[1]$} \\
\hline \multicolumn{19}{|l|}{ Immigratio } \\
\hline general & $\begin{array}{r}1 . \\
00\end{array}$ & & & & & & & & & & & & & & & & & \\
\hline \multicolumn{19}{|l|}{ [2] } \\
\hline Refugees & $\begin{array}{r}0 . \\
51\end{array}$ & $\begin{array}{c}1 . \\
00\end{array}$ & & & & & & & & & & & & & & & & \\
\hline $\begin{array}{l}\text { [3] Event } \\
\text { (dummy) }\end{array}$ & $\begin{array}{r}0 . \\
00\end{array}$ & $\begin{array}{c}0 . \\
05\end{array}$ & $\begin{array}{l}1 . \\
00\end{array}$ & & & & & & & & & & & & & & & \\
\hline
\end{tabular}




\begin{tabular}{|c|c|c|c|c|c|c|c|c|c|c|c|c|c|c|c|c|c|c|}
\hline Variable klein5 & 1 & 2 & 3 & 4 & 5 & 6 & 7 & 8 & 9 & 10 & 11 & 12 & 13 & 14 & 15 & 16 & 17 & 18 \\
\hline $\begin{array}{l}\text { [4] Linear spline } \\
\text { before } \\
\text { treatment (in } \\
\text { days) }\end{array}$ & $\begin{array}{c}- \\
0 . \\
01\end{array}$ & $\begin{array}{c}0 . \\
04\end{array}$ & $\begin{array}{c}0 . \\
56\end{array}$ & $\begin{array}{c}1 . \\
00\end{array}$ & & & & & & & & & & & & & & \\
\hline $\begin{array}{l}\text { [5] Linear spline } \\
\text { after treatment } \\
\text { (in days) }\end{array}$ & $\begin{array}{c}0 . \\
02\end{array}$ & $\begin{array}{c}0 . \\
06\end{array}$ & $\begin{array}{c}0 . \\
77\end{array}$ & $\begin{array}{r}0 . \\
43\end{array}$ & $\begin{array}{c}1 . \\
00\end{array}$ & & & & & & & & & & & & & \\
\hline [6] Age & $\begin{array}{c}0 . \\
06\end{array}$ & $\begin{array}{r}0 . \\
01\end{array}$ & $\begin{array}{l}- \\
0 . \\
07\end{array}$ & $\begin{array}{c}- \\
0 . \\
10\end{array}$ & $\begin{array}{c}- \\
04 \\
04\end{array}$ & $\begin{array}{r}1 . \\
00\end{array}$ & & & & & & & & & & & & \\
\hline [7] Age2 & $\begin{array}{c}0 . \\
05\end{array}$ & $\begin{array}{r}0 . \\
02\end{array}$ & $\begin{array}{c}- \\
0 . \\
08\end{array}$ & $\begin{array}{c}- \\
0 . \\
11\end{array}$ & $\begin{array}{c}0 . \\
05\end{array}$ & $\begin{array}{r}0 . \\
98\end{array}$ & $\begin{array}{r}1 . \\
00\end{array}$ & & & & & & & & & & & \\
\hline $\begin{array}{l}\text { Education } \\
\text { (dummies) }\end{array}$ & & & & & & & & & & & & & & & & & & \\
\hline $\begin{array}{l}\text { [8] ES- } \\
\text { ISCED II }\end{array}$ & $\begin{array}{c}0 . \\
05\end{array}$ & $\begin{array}{c}- \\
0 . \\
02\end{array}$ & $\begin{array}{c}- \\
0 . \\
01\end{array}$ & $\begin{array}{l}0 . \\
00\end{array}$ & $\begin{array}{c}- \\
0 . \\
02\end{array}$ & $\begin{array}{c}- \\
0 . \\
22\end{array}$ & $\begin{array}{c}- \\
0 . \\
15\end{array}$ & $\begin{array}{r}1 . \\
00\end{array}$ & & & & & & & & & & \\
\hline $\begin{array}{l}\text { [9] ES- } \\
\text { ISCED IIla }\end{array}$ & $\begin{array}{c}0 . \\
22\end{array}$ & $\begin{array}{r}0 . \\
12\end{array}$ & $\begin{array}{c}0 . \\
01\end{array}$ & $\begin{array}{c}0 . \\
04\end{array}$ & $\begin{array}{c}0 . \\
01\end{array}$ & $\begin{array}{r}0 . \\
21\end{array}$ & $\begin{array}{c}0 . \\
19\end{array}$ & $\begin{array}{c}- \\
0 . \\
24\end{array}$ & $\begin{array}{r}1 . \\
00\end{array}$ & & & & & & & & & \\
\hline $\begin{array}{l}\text { [10] ES- } \\
\text { ISCED IIIb }\end{array}$ & $\begin{array}{c}- \\
0 . \\
12\end{array}$ & $\begin{array}{c}- \\
0 . \\
09\end{array}$ & $\begin{array}{c}- \\
0 . \\
01\end{array}$ & $\begin{array}{c}0 . \\
00\end{array}$ & $\begin{array}{c}- \\
0 . \\
02\end{array}$ & $\begin{array}{c}- \\
0 . \\
24\end{array}$ & $\begin{array}{c}- \\
0 . \\
21\end{array}$ & $\begin{array}{c}- \\
0 . \\
06\end{array}$ & $\begin{array}{c}- \\
0 . \\
16\end{array}$ & $\begin{array}{r}1 . \\
00\end{array}$ & & & & & & & & \\
\hline $\begin{array}{l}\text { [11] ES- } \\
\text { ISCED IV }\end{array}$ & $\begin{array}{c}- \\
0 . \\
03\end{array}$ & $\begin{array}{r}0 . \\
05\end{array}$ & $\begin{array}{c}0 . \\
01\end{array}$ & $\begin{array}{c}0 . \\
00\end{array}$ & $\begin{array}{c}0 . \\
03\end{array}$ & $\begin{array}{r}0 . \\
00\end{array}$ & $\begin{array}{c}- \\
0 . \\
02\end{array}$ & $\begin{array}{c}- \\
0 . \\
16\end{array}$ & $\begin{array}{r}- \\
0 . \\
41\end{array}$ & $\begin{array}{c}- \\
0 . \\
11\end{array}$ & $\begin{array}{r}1 . \\
00\end{array}$ & & & & & & & \\
\hline $\begin{array}{l}\text { [12] ES- } \\
\text { ISCED V1 }\end{array}$ & $\begin{array}{c}- \\
0 . \\
08\end{array}$ & $\begin{array}{c}- \\
0 . \\
03\end{array}$ & $\begin{array}{c}0 . \\
00\end{array}$ & $\begin{array}{c}- \\
01 \\
01\end{array}$ & $\begin{array}{c}0 . \\
00\end{array}$ & $\begin{array}{c}0 . \\
01\end{array}$ & $\begin{array}{c}- \\
0 . \\
01\end{array}$ & $\begin{array}{c}- \\
0 . \\
11\end{array}$ & $\begin{array}{c}- \\
0 . \\
27\end{array}$ & $\begin{array}{c}- \\
0 . \\
07\end{array}$ & $\begin{array}{c}- \\
0 . \\
18\end{array}$ & $\begin{array}{c}1 . \\
00\end{array}$ & & & & & & \\
\hline $\begin{array}{l}\text { [13] ES- } \\
\text { ISCED V2 }\end{array}$ & $\begin{array}{c}- \\
0 . \\
17\end{array}$ & $\begin{array}{c}- \\
0 . \\
12\end{array}$ & $\begin{array}{l}- \\
0 .\end{array}$ & $\begin{array}{c}- \\
0 . \\
03\end{array}$ & $\begin{array}{c}- \\
0 . \\
02\end{array}$ & $\begin{array}{r}0 . \\
10\end{array}$ & $\begin{array}{c}0 . \\
07\end{array}$ & $\begin{array}{c}- \\
0 . \\
13\end{array}$ & $\begin{array}{r}- \\
0 . \\
33\end{array}$ & $\begin{array}{c}- \\
0 . \\
09\end{array}$ & $\begin{array}{c}- \\
0 . \\
22\end{array}$ & $\begin{array}{c}- \\
0 . \\
14\end{array}$ & $\begin{array}{l}1 . \\
00\end{array}$ & & & & & \\
\hline $\begin{array}{l}\text { [14] Female } \\
\text { (dummy) }\end{array}$ & $\begin{array}{c}0 . \\
03\end{array}$ & $\begin{array}{c}0 . \\
04\end{array}$ & $\begin{array}{c}0 . \\
02\end{array}$ & $\begin{array}{l}0 . \\
02\end{array}$ & $\begin{array}{c}0 . \\
02\end{array}$ & $\begin{array}{c}- \\
0 . \\
01\end{array}$ & $\begin{array}{c}0 . \\
00\end{array}$ & $\begin{array}{c}0 . \\
09\end{array}$ & $\begin{array}{r}0 . \\
03\end{array}$ & $\begin{array}{r}0 . \\
00\end{array}$ & $\begin{array}{c}- \\
0 . \\
05\end{array}$ & $\begin{array}{c}- \\
0 . \\
09\end{array}$ & $\begin{array}{r}0 . \\
01\end{array}$ & $\begin{array}{c}1 . \\
00\end{array}$ & & & & \\
\hline \multicolumn{19}{|l|}{$\begin{array}{l}\text { Residence } \\
\text { (dummies) }\end{array}$} \\
\hline $\begin{array}{l}15] \\
\text { Suburbs or } \\
\text { outskirts of } \\
\text { big city }\end{array}$ & $\begin{array}{c}- \\
0 . \\
06\end{array}$ & $\begin{array}{c}- \\
07\end{array}$ & $\begin{array}{l}0 . \\
02\end{array}$ & $\begin{array}{l}- \\
0 .\end{array}$ & $\begin{array}{c}0 . \\
02\end{array}$ & $\begin{array}{r}0 . \\
04\end{array}$ & $\begin{array}{r}0 . \\
04\end{array}$ & $\begin{array}{c}- \\
0 . \\
04\end{array}$ & $\begin{array}{c}- \\
0 . \\
01\end{array}$ & $\begin{array}{l}0 . \\
00\end{array}$ & $\begin{array}{c}- \\
0 . \\
01\end{array}$ & $\begin{array}{c}0 . \\
03\end{array}$ & $\begin{array}{r}0 . \\
05\end{array}$ & $\begin{array}{c}- \\
0 . \\
04\end{array}$ & $\begin{array}{r}1 . \\
00\end{array}$ & & & \\
\hline
\end{tabular}




\section{$\begin{array}{lllllllllllllllllll}\text { Variable klein5 } & 1 & 2 & 3 & 4 & 5 & 6 & 7 & 8 & 9 & 10 & 11 & 12 & 13 & 14 & 15 & 16 & 17 & 18\end{array}$}

[16] Town

or small

city

$\begin{array}{cccccccccccccccc}0 . & 0 . & 0 . & 0 . & 0 . & 0 . & 0 . & 0 . & 0 . & 0 . & 0 . & 0 . & 0 . & 0 . & 0 . & 1 .\end{array}$

[17]

Country

village

$\begin{array}{llllllllllllllll}11 & 06 & 02 & 01 & 04 & 04 & 04 & 00 & 05 & 02 & 00 & 00 & 06 & 02 & 32 & 00\end{array}$

[18] Farm

or home in

countrysid

$$
\text { e }
$$

$\begin{array}{lllllllllllllllllll}0 . & 0 . & 0 . & 0 . & 0 . & 0 . & 0 . & 0 . & 0 . & 0 . & 0 . & 0 . & 0 . & 0 . & 0 . & 0 . & 0 . & 1 .\end{array}$ $\begin{array}{llllllllllllllllll}01 & 01 & 03 & 00 & 03 & 04 & 04 & 03 & 01 & 01 & 03 & 01 & 06 & 03 & 07 & 13 & 11 & 00\end{array}$

\section{Employment}

status

(dummies)

[19] In

education

$\begin{array}{lllllllllllllllll}0 . & 0 . & 0 . & 0 . & 0 . & 0 . & 0 . & 0 . & 0 . & 0 . & 0 . & 0 . & 0 . & 0 . & 0 . & 0 . & 1 .\end{array}$

$\begin{array}{lllllllllllllllll}04 & 06 & 01 & 01 & 04 & 05 & 05 & 06 & 01 & 04 & 04 & 03 & 06 & 02 & 28 & 54 & 00\end{array}$

$$
\begin{array}{llllllllllllllllll}
01 & 01 & 03 & 00 & 03 & 04 & 04 & 03 & 01 & 01 & 03 & 01 & 06 & 03 & 07 & 13 & 11 & 00
\end{array}
$$

[20]

Unemploy

ed, looking

for a job.

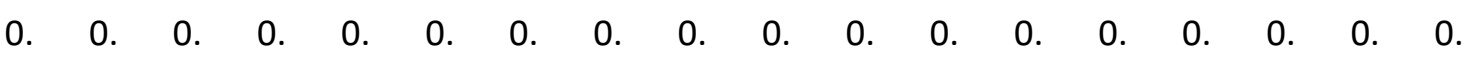

$\begin{array}{llllllllllllllllll}09 & 01 & 01 & 01 & 01 & 06 & 07 & 04 & 04 & 01 & 02 & 00 & 05 & 03 & 01 & 00 & 02 & 02\end{array}$

[21]

Unemploy

ed, not

looking for

a job

$\begin{array}{lllllllllllllllllll}0 . & 0 . & 0 . & 0 . & 0 . & 0 . & 0 . & 0 . & 0 . & 0 . & 0 . & 0 . & 0 . & 0 . & 0 . & 0 . & 0 . & 0 .\end{array}$

$\begin{array}{llllllllllllllllll}02 & 05 & 02 & 02 & 02 & 02 & 03 & 02 & 03 & 07 & 03 & 01 & 03 & 00 & 00 & 02 & 02 & 01\end{array}$

[22]

Permanent

ly sick or

disabled

$\begin{array}{llllllllllllllllll}0 . & 0 . & 0 . & 0 . & 0 . & 0 . & 0 . & 0 . & 0 . & 0 . & 0 . & 0 . & 0 . & 0 . & 0 . & 0 . & 0 . & 0 .\end{array}$

$\begin{array}{llllllllllllllllll}05 & 01 & 00 & 01 & 03 & 04 & 03 & 05 & 01 & 06 & 04 & 01 & 03 & 01 & 01 & 02 & 02 & 02\end{array}$

[23]

$\begin{array}{lllllllllllllllllll}\text { Retired } & 0 . & 0 . & 0 . & 0 . & 0 . & 0 . & 0 . & 0 . & 0 . & 0 . & 0 . & 0 . & 0 . & 0 . & 0 . & 0 . & 0 . & 0 .\end{array}$

$\begin{array}{llllllllllllllllll}04 & 03 & 08 & 11 & 07 & 67 & 73 & 04 & 13 & 11 & 04 & 04 & 02 & 03 & 00 & 06 & 08 & 04\end{array}$

[24]

$\begin{array}{lllllllllllllllllll}\text { Housework } & 0 . & 0 . & 0 . & 0 . & 0 . & 0 . & 0 . & 0 . & 0 . & 0 . & 0 . & 0 . & 0 . & 0 . & 0 . & 0 . & 0 . & 0 .\end{array}$ $\begin{array}{llllllllllllllllll}00 & 01 & 01 & 01 & 02 & 00 & 02 & 00 & 03 & 02 & 01 & 01 & 00 & 20 & 02 & 00 & 03 & 02\end{array}$

[25] Other

$\begin{array}{llllllllllllllllll}0 . & 0 . & 0 . & 0 . & 0 . & 0 . & 0 . & 0 . & 0 . & 0 . & 0 . & 0 . & 0 . & 0 . & 0 . & 0 . & 0 . & 0 .\end{array}$ $\begin{array}{llllllllllllllllll}04 & 02 & 01 & 00 & 02 & 09 & 08 & 00 & 06 & 15 & 00 & 02 & 03 & 02 & 02 & 01 & 03 & 02\end{array}$ 


\begin{tabular}{lcccccccccccccccccc}
\hline Variable klein5 & 1 & 2 & 3 & 4 & 5 & 6 & 7 & 8 & 9 & 10 & 11 & 12 & 13 & 14 & 15 & 16 & 17 & 18 \\
\hline [26] Migration & & & & & & & & & & & & & & & & & & \\
background & - & - & & & & - & - & & - & & - & - & - & & - & & & - \\
(dummy) & 0. & 0. & 0. & 0. & 0. & 0. & 0. & 0. & 0. & 0. & 0. & 0. & 0. & 0. & 0. & 0. & 0. & 0. \\
& 05 & 03 & 02 & 01 & 00 & 10 & 10 & 05 & 01 & 06 & 04 & 01 & 03 & 01 & 02 & 00 & 02 & 04
\end{tabular}

Source: ESS8e02.

Table A4: Robustness Test via Placebo

\begin{tabular}{|c|c|c|c|c|}
\hline Variable klein1 & M9 & M10 & M11 & M12 \\
\hline \multicolumn{5}{|l|}{ Treatment variables } \\
\hline \multicolumn{5}{|l|}{ Simple experimental design } \\
\hline \multicolumn{4}{|l|}{ Treatment ( 0 before event, 1 after } & \\
\hline event) & $(0.048)$ & $(0.047)$ & & \\
\hline \multicolumn{5}{|l|}{ Regression discontinuity design } \\
\hline \multirow[t]{2}{*}{ Linear spline before treatment (days) } & & & -0.001 & -0.001 \\
\hline & & & $(0.001)$ & $(0.001)$ \\
\hline \multirow[t]{2}{*}{ Linear spline after treatment (days) } & & & 0.003 & 0.003 \\
\hline & & & $(0.002)$ & $(0.002)$ \\
\hline \multicolumn{5}{|l|}{ Covariate adjustment } \\
\hline Age & & -0.013 & & -0.013 \\
\hline Age2 & & 0.000 & & 0.000 \\
\hline \multicolumn{5}{|l|}{ Education (ref.: ES-ISCED I) } \\
\hline ES-ISCED II & & 0.106 & & 0.104 \\
\hline ES-ISCED IIla & & 0.184 & & 0.183 \\
\hline ES-ISCED IIIb & & -0.268 & & -0.273 \\
\hline ES-ISCED IV & & -0.073 & & -0.073 \\
\hline ES-ISCED V1 & & -0.172 & & -0.171 \\
\hline ES-ISCED V2 & & $-0.349 *$ & & $-0.352 *$ \\
\hline Female (ref.: Male) & & -0.065 & & -0.061 \\
\hline
\end{tabular}


Suburbs or outskirts of big city

Town or small city

Country village
0.103
0.105

Farm or home in countryside
0.160
0.161

Employment status (ref.: Paid work)

In education

$\begin{array}{ll}-0.384 * * * & -0.379 * *\end{array}$

Unemployed, looking for a job.
0.210
0.208

Unemployed, not looking for a job
0.164
0.160

Permanently sick or disabled

$\begin{array}{ll}0.142 & 0.134\end{array}$

Retired

$\begin{array}{ll}-0.028 & -0.029\end{array}$

Housework

$\begin{array}{ll}-0.092 & -0.096\end{array}$

Other

$\begin{array}{ll}-0.347 * & -0.342\end{array}$

Migration background (ref.: no)

$\begin{array}{ll}-0.121 & -0.120\end{array}$

Constant $-0.003$

0.369 0.053

0.415

Statistics

\begin{tabular}{lcccc} 
AIC & 7424.059 & 7302.438 & 7423.518 & 7301.921 \\
BIC & 7435.801 & 7437.478 & 7441.132 & 7442.833 \\
R2 & 0.000 & 0.061 & 0.001 & 0.061 \\
N & 2621 & 2621 & 2621 & 2621 \\
\hline
\end{tabular}

Notes: ${ }^{*} p<0.05 ;{ }^{* *} p<0.01 ;{ }^{* * *} p<0.001$ (two-sided tests). These regressions use the $19^{\text {th }}$ December 2014 as a placebo test. 
Source: ESS7e2_2

Table A5: Top terms per topic

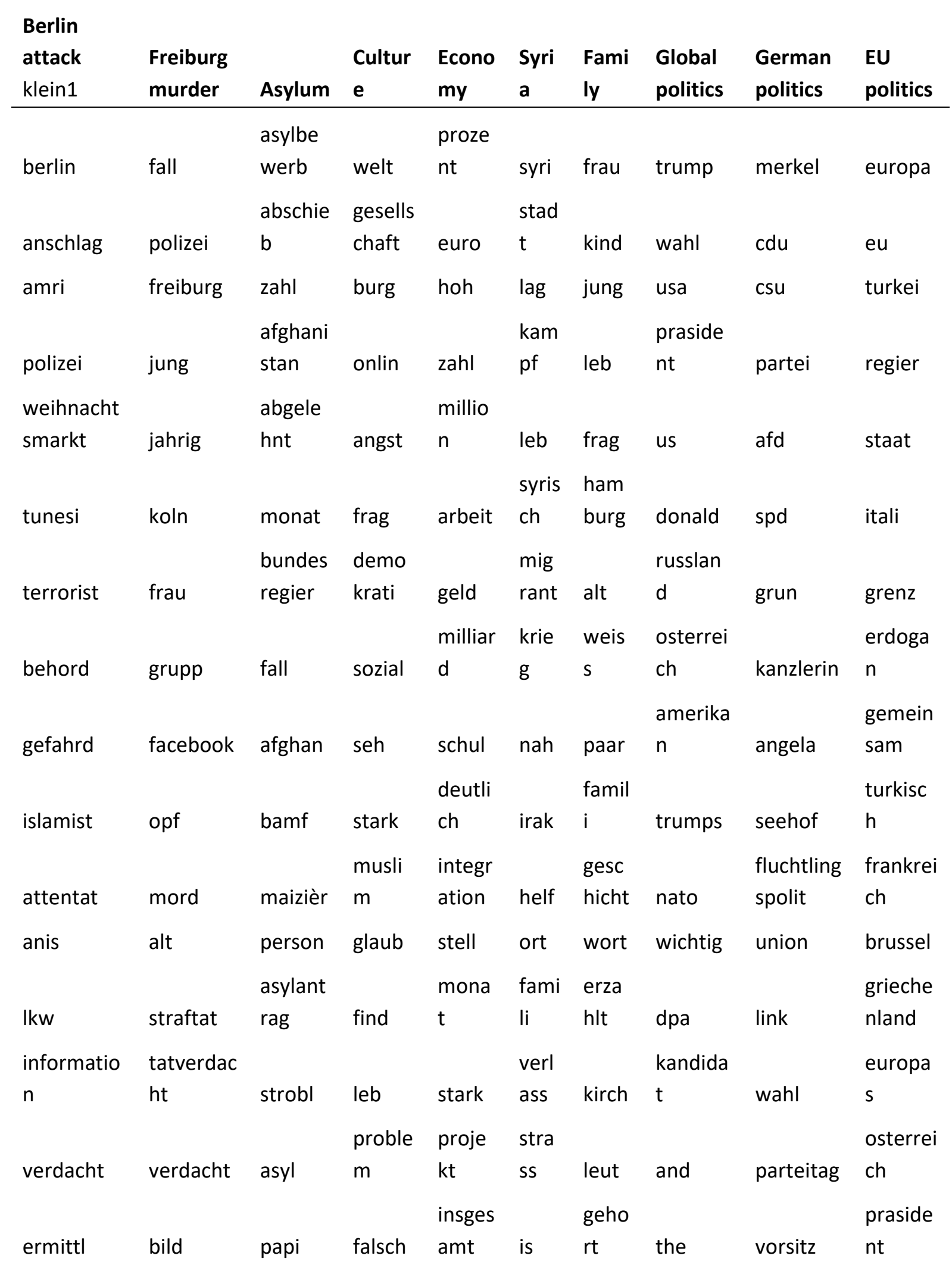




\begin{tabular}{llllllllllll} 
offenbar & medi & staat & staat & kost & al & lass & partei & obergren & fluchtli \\
entsch & & fluc & angs & & & ngskris \\
verletzt & vorwurf & freiwill & eid & liegt & ht & $\mathrm{t}$ & kunftig & rot & union \\
& & & & wichti & gre & & & & parlam \\
terror & studentin & schutz & wert & $\mathrm{g}$ & $\mathrm{nz}$ & haus & hof & chef & ent \\
& & & & & & schw & & bundesk & \\
mutmass & ermittl & fordert & lass & laut & ost & eig & alt & anzlerin & welt \\
\hline
\end{tabular}

